\title{
2009s-44
}

\section{Global Security Policies Against Terrorism and the Free Riding Problem: An Experimental Approach}

\author{
Nathalie Colombier, David Masclet,
} Daniel Mirza, Claude Montmarquette

\section{Série Scientifique \\ Scientific Series}

\author{
Montréal \\ Octobre 2009
}

(C) 2009 Nathalie Colombier, David Masclet, Daniel Mirza, Claude Montmarquette. Tous droits réservés. All rights reserved. Reproduction partielle permise avec citation du document source, incluant la notice (C).

Short sections may be quoted without explicit permission, if full credit, including (C) notice, is given to the source.
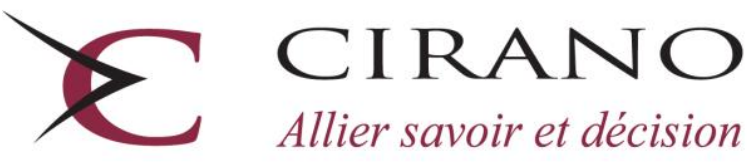

Allier savoir et décision

Centre interuniversitaire de recherche en analyse des organisations 


\section{CIRANO}

Le CIRANO est un organisme sans but lucratif constitué en vertu de la Loi des compagnies du Québec. Le financement de son infrastructure et de ses activités de recherche provient des cotisations de ses organisations-membres, d'une subvention d'infrastructure du Ministère du Développement économique et régional et de la Recherche, de même que des subventions et mandats obtenus par ses équipes de recherche.

CIRANO is a private non-profit organization incorporated under the Québec Companies Act. Its infrastructure and research activities are funded through fees paid by member organizations, an infrastructure grant from the Ministère du Développement économique et régional et de la Recherche, and grants and research mandates obtained by its research teams.

\section{Les partenaires du CIRANO}

Partenaire majeur

Ministère du Développement économique, de l'Innovation et de l'Exportation

\section{Partenaires corporatifs}

Banque de développement du Canada

Banque du Canada

Banque Laurentienne du Canada

Banque Nationale du Canada

Banque Royale du Canada

Banque Scotia

Bell Canada

BMO Groupe financier

Caisse de dépôt et placement du Québec

DMR

Fédération des caisses Desjardins du Québec

Gaz de France

Gaz Métro

Hydro-Québec

Industrie Canada

Investissements PSP

Ministère des Finances du Québec

Power Corporation du Canada

Raymond Chabot Grant Thornton

Rio Tinto

State Street Global Advisors

Transat A.T.

Ville de Montréal

\section{Partenaires universitaires}

École Polytechnique de Montréal

HEC Montréal

McGill University

Université Concordia

Université de Montréal

Université de Sherbrooke

Université du Québec

Université du Québec à Montréal

Université Laval

Le CIRANO collabore avec de nombreux centres et chaires de recherche universitaires dont on peut consulter la liste sur son site web.

Les cahiers de la série scientifique (CS) visent à rendre accessibles des résultats de recherche effectuée au CIRANO afin de susciter échanges et commentaires. Ces cahiers sont écrits dans le style des publications scientifiques. Les idées et les opinions émises sont sous l'unique responsabilité des auteurs et ne représentent pas nécessairement les positions du CIRANO ou de ses partenaires.

This paper presents research carried out at CIRANO and aims at encouraging discussion and comment. The observations and viewpoints expressed are the sole responsibility of the authors. They do not necessarily represent positions of CIRANO or its partners. 


\title{
Global Security Policies Against Terrorism and the Free Riding Problem: An Experimental Approach*
}

\author{
Nathalie Colombier ${ }^{\dagger}$, David Masclet \\ Daniel Mirza ${ }^{\S}$, Claude Montmarquette
}

\begin{abstract}
Résumé
L'attentat qui a frappé le World Trade Center a fait la lumière sur l'urgence de mettre en œuvre des mesures préventives contre le terrorisme et d'améliorer la collaboration au sein du système de sécurité mondial en faisant intervenir tous les pays. Toutefois, on ne peut tenir la coordination internationale pour acquise car elle est souvent inefficace et risque d'échouer pour plusieurs raisons. L'échec de la coordination s'explique peut-être de façon plus marquée par le fait que les actions collectives contre le terrorisme sont susceptibles de souffrir d'un problème bien connu appelé resquillage (Sandler et Enders, 2004). Dans le présent document, nous examinons au moyen d'expériences le dilemme au sujet de la collaboration qui est posé par les politiques contre le terrorisme et nous tentons d'établir dans quelle mesure la politique internationale de dissuasion peut souffrir du phénomène de resquillage. Dans le cadre de notre jeu, les contributions au compte collectif ne visent pas à augmenter la production du bien public, mais plutôt à diminuer la probabilité qu'un événement stochastique détruise le bien en question. Un pays pourrait choisir de resquiller, soit en n'investissant pas dans la politique internationale de dissuasion, mais en utilisant plutôt toutes ses ressources pour sa protection nationale. Il pourrait aussi choisir d'ignorer totalement le terrorisme et d'investir dans certains autres projets. Nous nous penchons aussi sur l'influence qu'exercent les organismes qui permettent de sanctionner ou de récompenser les autres pays dans le but de faciliter la coordination en matière de politique de dissuasion. Nous constatons que, en l'absence d'encouragements institutionnels et une fois l'aversion à l'égard du risque maîtrisée, la plupart des pays font défection en investissant très peu dans les actions collectives contre le terrorisme et beaucoup dans leur propre protection. Par contre, l'introduction de mécanismes d'encouragement axés sur les punitions ou les récompenses améliore considérablement l'ampleur de la participation au compte collectif pour la sécurité.
\end{abstract}

Mots clés : Structure des expériences, économie expérimentale, terrorisme, conflits, économie du secteur public

\footnotetext{
* We thank participants in seminars at the 2009 APET Meetings in Lyon, France for constructive and helpful comments. We are also thankful to Elven Priour and Nathalie Viennot for their able research assistance.

Financial support from the Agence Nationale de Recherche (ANR) through the project "GTCI Guerre, terrorisme et commerce international" is gratefully acknowledged.

† CREM (CNRS - Université de Rennes 1); 7, place Hoche, 35065 Rennes, France. Tel: +33 223233335.

Email: nathalie.colombier@univ-rennes1.fr

+ CREM (CNRS - Université de Rennes 1) and CIRANO, 7, place Hoche, 35065 Rennes, France.

Tel: +3322323 33 18. Email: david.masclet@univ-rennes1.fr

${ }^{\S}$ GERCIE-Université François Rabelais de Tours, 50, avenue Jean Portalis, 37000 Tours, France.

Tel: +33 2473610 76. Email: daniel.mirza@univ-tours.fr

** + CIRANO, 2020 University, $25^{\mathrm{e}}$ étage, Montréal, (Québec), Canada, H3A 2A5.

Tel.: (514) 985-4001. Email: montmarc@ cirano.qc.ca
} 


\begin{abstract}
The World Trade Center attack has shed light on the urgent need to implement preventing measures against terrorism and to enhance cooperation in the global security system for all countries. However, international coordination cannot be taken for granted. It is often ineffective and likely to fail for several reasons. Perhaps the more prominent reason to explain failure in coordination is that collective actions against terrorism may suffer from the well known free riding problem (Sandler and Enders, 2004). In this paper we experimentally investigate cooperation dilemma in counterterrorism policies by measuring to what extent international deterrence policy may suffer from free riding. In our game, contributions to the group account do not aim to increase the production of the public good but instead seek to decrease the probability that a stochastic event destroys the good. A country could choose to free ride by investing nothing in the international deterrence policy and instead invest all its resources in its own national protection or even choose to ignore totally terrorism by investing on alternative projects. We also look at the effects of institutions that allow sanctioning and rewarding of other countries to facilitate coordination on deterrence policy. We find that, in absence of institutional incentives and after controlling for risk aversion, most of countries defect by investing very weakly in collective actions against terrorism while largely investing to protect themselves. In contrast, the introduction of punishment/reward incentive systems improves significantly the contribution level to the collective security account.
\end{abstract}

Keywords: Design of experiments, experimental economics, terrorism, conflicts,public economics.

Codes JEL : D72, C91 


\section{Introduction}

Terror actions are becoming increasingly global. Terrorism new face today is shaped by footloose terror organizations setting-up local cells, backed by logistical support from 'headquarter' type organizations, like Al-Qaeda or the Taliban. ${ }^{1}$ Interestingly enough, this international movement of terrormaking is found to be more taken place in developing countries than in rich countries. One possible reason is due to the relatively higher share of resources devoted to security for own protection in the North. The illustration of 9/11 events is remarkable in this respect. After September 11, the United States created the department of Homeland Security and increased dramatically the share of US budget devoted to security against terror from $\$ 15$ billion in 2001 to about $\$ 32$ billion in 2003 (Chaffin 2004).

This increase in own protection by the US and more broadly by the North, might be displacing the problem of terrorism to the South, however. Due to lack of security resources, many developing countries like the Philippines, Indonesia or Pakistan are becoming highly attractive places for terrorist organizations where to be based and act. According to Sandler and Enders, (2004) "terrorists will naturally seek out the weakest link - the country with the least security - in planning their next attack".

Nevertheless, besides inward oriented protection the US has also joined some of its resources with other countries ones -mainly in North and Central America together with the European countries- to implement measures that are mutually protective. The heavily mediatized cooperation programs with the EU on the extension of the Container Security Initiative (CSI) to Europe together with the obligation of including biometric identifiers in European passports provide examples. Indeed, as terror threat becomes global, so are security measures. Global measures need global cooperation. The reason behind this is that is doubtful that a country alone can achieve full security by itself, as the risk it faces also depends on the actions taken by others. It is increasingly recognized that even the best national policy is generally inefficient in absence of an international coordination with our allies. Collaborative actions and sharing of information have thus become key fundamental elements in a globalized world in order to protect its territory against terrorism.

However, international coordination cannot be taken for granted. It is often ineffective and likely to fail for several reasons. The countries' interests may be divergent, which would make more difficult to find an agreement on a collective approach to fight terrorism. For example, governments may disagree on who are the terrorists and on the means to stop their actions. Some governments may be reluctant to sacrifice their autonomy over security matters. Another reason relies on the idea that perception of risk may differ among countries and countries have different attitudes toward risk. Less risk averse countries may have less incentives to agree on a collective security policy. Finally, some countries may choose not to join a coalition against terrorism for political or economic strategic reasons. Among all these reasons, perhaps the more prominent reason to explain failure in coordination, is that collective actions against terrorism may suffer from the well known free riding problem (Sandler, 2003; Sandler

\footnotetext{
${ }^{1}$ See for instance Steinberg (2008), Steinberg and Werenfels (2007) and more analytically Desousa, Mirza and Verdier (2009) on terrorism networks and globalization of terrorism.

${ }^{2}$ Some countries may be also incited not to engage in international anti terrorism policies in order to avoid (reduce) the risk of being a potential target of a future terrorist attack by adopting a complacent attitude toward terrorists.
} 
and Enders, 2004). As pointed out by several authors, global security policies may be perceived as an international Globlal Public Good (GPG) characterized by an incentive for countries to defect by investing in alternative projects (for example, education, social security, etc.) while profiting from the protection policy implemented by others (Sandler and Enders, 2004). ${ }^{3}$ Alternatively, the countries may also choose to invest in their own national protection, which would reduce the conditional probability of being hit in case of a future attack while profiting from an international protection policy implemented by other countries. By investing in their own protection, the countries will be better protected from a terrorist attack avoiding to appear as the weakest links.

Counterterrorism policies have been extensively investigated in the traditional literature on the economics of terrorism studies (see Enders and Sandler, 2006, chapters 4-6 for a detailed analysis and survey). ${ }^{4}$ Sandler and Enders (2004) showed the necessity for the governments to join their forces to reach collective actions against terrorism. The authors also pointed out the circumstances that impede cooperation between governments. In particular Sandler and Enders shed light on the existence of a cooperation dilemma in the context of international cooperation against terrorism. Enders and Sandler (2006) distinguish between defensive and proactive policies against terror. While defensive policies in one country happen to displace terrorism to others, thus providing negative international externalities, proactive security measures like freezing assets and military sustained operations against terrorists presumed headquarters are usually viewed to be international public goods from which all countries can benefit. ${ }^{5}$ Proactive security measures might be undertaken by one or a few countries, but in the case of terrorist networks which span over many countries, the measures become more efficient when they are undertaken globally. On the empirical side, using time series analysis, Enders, Sandler and Cauley (1990) investigate the effectiveness of international conventions/treaties related to the control and prevention of international terrorism. They found no evidence that international conventions/treaties have had a statistically significant impact on explaining crimes against diplomats and skyjackings. The reason why these international cooperation measures fail to reduce terror is that they do not possess an enforcement mechanism and many countries simply do not have the capacities to comply because of lack of resources.

\footnotetext{
${ }^{3}$ For illustration, Sandler (2003) uses a simple $2 \times 2$ game representation in which two players - the United States (US) and the European Union (EU) - must jointly decide efforts allocated toward counterterrorist policies. This is a pure public good because the benefits achieved from counterterrorism depend on the countries' cumulative efforts. Counterterrorism actions reduce the probability of any subsequent terrorist attack for both players. However from each country's viewpoint, there is a dominant strategy not to act.

${ }^{4}$ Several theoretical studies examined the determinants of terrorism and how it spreads as a contagion phenomenon (Midlarsky, 1970, 1978; Midlarsky, Crenshaw and Yoshida, 1980; Hamilton and Hamilton, 1983). Other studies investigated the question to what extent it's worth negotiating with terrorists in cases of hostage-taking situations (Scott, 1993, Sandler and Enders, 2004). These studies rely on the idea that terrorism can be modelized as a negotiation game between the terrorists and the governments (Sandler et al. 1983). Frey and Luechinger (2004) investigated the importance of decentralizing activities as a way to reduce the impact of terrorism as the decentralization of activities may be an optimal way to reduce the costs of a terrorist attack because several different centres are more difficult to destabilise than a unique strategic centre.

${ }^{5}$ That being said, proactive policies might also be associated with costs (new terrorists attacks) if these result in freedom losses and provide anger among potential terrorists (Rosendorff and Sandler, 2005).
} 
In this paper we use a laboratory experiment to investigate cooperation dilemma in ccounterterrorism policies. To do so, following Sandler (2003) and Sandler and Enders, (2004), we first model international security as a public good to which every country endowed with constrained resources has to decide how much of its national resources to invest in international collective actions in order to reduce expected losses from a terrorist attack. In our game, a country could choose to free ride by investing nothing in the international deterrence policy and instead could invest all its resources in its own national protection through a private "insurance" good (i.e. defends its own territory and nothing else). By doing so, the country displaces terror to other countries which have chosen to invest less in their own protection. A country can also choose to ignore totally terrorism by investing on other alternative projects (for example education, health policy, social security, etc.). Although these games are stylized and simple, they illustrate a number of important features of international actions to deter terrorism.

We then provide empirical evidence of free riding problem in counterterrorism policies by conducting a controlled laboratory experiment. Testing models dealing with governments'counterterrorism efforts by using laboratory methodology that involves small number of players performing abstract tasks and interacting with one another for finite repeated number of periods, might be met with some skepticism. Of course many economic and political factors other than security drive terrorism. Furthermore counterterrorism may have several macroeconomic implications, which might be regarded as a critical issue to investigate such phenomena using small-scale laboratory evidence. In this paper we are not interested in reproducing real-world terrorism activity per se. Instead we focus on explicit micro-foundations of counterterrorism policies by studying how individual agents invest to reduce the probability of losses, and/or how they change their behavior after a loss, which can be directly tested in the laboratory. Precisely we highlight two particular features of counterterrorism : (1) the fact that global security is a public good by itself and (2) the fact that alternative private protection policies displace terror activities to less secure countries. The laboratory has the advantage of measuring microeconomic causal relationships in a controlled environment (e.g. the political, social and religious context), defining a priori the reference group, rather than having to infer it from survey data, and of avoiding any possible role for contextual effects, which allows achieving a high degree of internal validity. ${ }^{6}$

Two sets of questions are addressed in this paper. First, we seek to investigate the general conditions for countries to be incited to cooperate to an international security policy. Precisely, we investigate the factors that might influence cooperation including perception of risk. The second aim of this paper has a more normative flavour. We explore here the ability of different kind of institutions to facilitate

\footnotetext{
${ }^{6}$ Several authors have highlighted the existence of a trade-off between internal and external validity. While internal validity generally requires abstraction and simplification, this is generally made at the cost of a decreasing external validity. The tradition of modeling in economics relies strongly on internal validity. According to Plott, "Experimental economics' revolutionary achievement consisted of shifting the focus from whether a certain experiment reproduces a real-world system accurately to whether it accurately tests a theory or model.[...] Once models became the focus of research the simplicity of an experiment and perhaps even the absence of features of more complicated economies became an asset. The experiment should be judged by the lessons it teachs about the theory and not by its similarity what nature might have happened to have created" (Plott, 1991, p906). The way our experiment is designed is perfectly in line with this tradition since it does not seek to reproduce a real world situation but rather aims at testing micro-foundations of counter-terrorism.
} 
cooperation in such collective actions. Precisely we set two types of institutions that could facilitate cooperation: one which uses reprisals in case of non-cooperating behaviours and one which allows for rewards in case of cooperation. Reprisals would be used against countries that defect by not entering the international coalition and that may be perceived to some extent complaisant toward terrorists. These sanctions can include reductions of commercial ties or trade embargo. ${ }^{7}$ The second institutional policy relies on the use of rewards including for example monetary transfers, development and assistant aid toward countries that choose to cooperate against international terrorism. We then ask which of these institutions is the more efficient and induces the best incentive to contribute to the collective antiterrorist policy.

Our experiment consists of three treatments. In a first treatment called baseline treatment, countries have to choose between investing in an international collective action, investing for their own national protection or investing in alternative policies not directly associated with security. The total amount of tokens invested in the collective action by all countries reduces the probability of an international attack. The tokens invested in the national protection reduce one probability of being hit conditional to the fact that a terrorist attack occurs. For each country, this conditional probability depends on the amount invested for its protection relatively to the amount invested by the others. If all countries invest nothing or exactly the same amount for national protection, this conditional probability is the same for all countries. Finally, investing in an alternative policy outside the security issue does not change the probability of an attack. The second treatment called sanction treatment is identical to the previous one, except that after being informed about the individual contribution level of each other country, a country has the opportunity to assign costly points of punishment. The third treatment, called the reward treatment, is similar to the punishment treatment except that each country can assign costly reward points that improve the payoffs of those who receive them.

Our experimental design has the flavour of a public good to be financed by voluntary contributions (e.g. Davis and Holt, 1993). However it differs substantially from a standard VCM experiment in that contributions to the group account do not aim to increase the production of the public good but instead seek to decrease the probability that a stochastic event destroys the good. In the same vein, Dickinson (1998) introduced risk into the production of the public good and compared a situation where the risk is exogenously determined and a situation where the risk decreases with the contribution level. His findings indicate that the introduction of risk into the production of a public good has a weakly negative effect on voluntary contributions. Our paper is also related to Keser and Montmarquette (2008) who examine voluntary private contributions to reduce the probability of a public loss in the context of an experimental study. The authors find that subjects make positive contributions although the contribution level is lower than in the typical experiments on voluntary contributions to fund public goods. Another interesting result from this study is that the occurrence of a loss decreases the aggregate contribution level. Our paper also relates to Hess Holt and Smith (2007) that investigated how subjects can coordinate investments in order to reduce the probability of losses of a terrorist attack in the context of coordination games. The main finding of this study is that coordination can

\footnotetext{
7 Sanctions can also take on symbolic forms. For example, the fries in the Congress cafeteria were renamed "freedom fries" as a retaliation against France's refusal to enter coalition against terrorism and to support U.S. proposals in the UN Security Council for military action to invade Iraq.
} 
be enhanced if players are allowed to decide sequentially instead of choosing simultaneously.

Our study brings several important innovations to these previous experiments. First, the issue of counterterrorism policies in a VCM setting has, to our knowledge, not been previously studied experimentally. Second, we investigate in more detail the determinants of failure in coordination in global security policy. Third, we seek to explore the ability of sanctioning and rewarding mechanisms of institutions to facilitate cooperation in collective actions against terrorism. To some extent our study is in line with previous experiments inspired by Fehr and Gaechter, 2000 that investigated the effects of sanction and/or rewards in VCM contexts (Fehr and Gächter's, 2000; Dickinson, 2001; Fehr and Rockenbach , 2003 Masclet et al., 2003; Egas and Riedl, 2005; Bochet, Page, and Putterman, 2006; Sefton et al., 2007; Carpenter, 2007; Houser et al. 2008). Sefton et al. (2007) investigated the combined use of rewards and punishments in repeated linear public goods games. They find that introducing these institutions results in higher contributions to the public good. The authors also observe that sanctions are more effective than punishment. In a different context, a two-person proposer-responder game, Andreoni et al. (2003) find similar results, showing that rewards are much less effective than sanctions while the combination of both reward and punishment has a very strong effect on cooperation.

To anticipate our results, our experiment replicates remarkably many predictions from previous theoretical study done by Sandler and Enders, (2004). We find that, in absence of institutional incentives and after controlling for risk aversion, most of countries defect by investing very weakly in collective actions against terrorism while largely investing to protect themselves. The introduction of punishment/reward incentive systems improves significantly the contribution level to the collective security account, however. These results are consistent with previous results on VCM with reward and/or sanction mechanisms. Nevertheless, and in contrast to previous studies, we find that in a deterrence policy context rewards seem to be more effective than punishments in deterring free riding and improving social welfare.

The remainder of the paper is organized as follows. Section 2 details our experimental design and presents the theoretical predictions of the model. The results of the study are presented in section 3. Section 4 presents our concluding remarks.

\section{Experimental design}

\subsection{The game}

Let's consider $n$ players, endowed with an initial wealth $W$ in UME and facing a potential external shock that could destroy a large part of their wealth. At each period, the participants receive $d$ UME. The players have then the possibility to distribute this amount across three different types of investments: an investment to contribute to the international public good which aims at reducing the probability of occurrence of an act, one which insures better national protection against a terrorist act that eventually occurs (ie. private protection), and finally, an investment in an alternative program. The following equation captures the decisional process:

$$
(d-X-Y)-\left[p^{*}-\left(X_{i}+\sum_{i \neq j} X_{j}\right) \frac{a}{n d}\right] \cdot\left[\frac{1}{n}-\frac{1}{n d}\left(Y_{i}-\frac{\sum Y}{n}\right)\right] . c
$$

The first term $(d-X-Y)$ expresses the investment that is left out for alternative programs after investments in the private and public protection. $X$ and $Y$ are the amounts 
respectively invested by a participant in the international counterterrorism action and for national protection. $Y$ can be seen as a private insurance good.

The second term expresses the ex-post probability of occurrence of an act. $p^{*}$ is the probability of occurrence of an international attack anywhere in the world if no one invests in international protection. If all participants invest all their tokens $d$ in $X$, this probability is reduced by $a$. Otherwise, it is reduced by $a$ times the total share of investing in the public good $\left(X_{i}+\sum_{i \neq j} X_{j}\right) / n d$.

The last term between brackets presents the relative (ex-post) probability of a participant (representing a country) to be hit if an international attack occurs. For each participant, this conditional probability depends on the amount $Y$ invested for the national protection relatively to the amount invested by the others. If all participants invest nothing in $Y$ or exactly the same amount, the conditional probability of being hit is $\frac{1}{n}$ for all. This conditional probability is reduced (increased) by a given factor for the participant investing more (less) than the mean investment in $Y .^{8}$ Finally $c$ is the cost of being hit.

In our experiment $W$ is set to $6000 \mathrm{UME}$ and $\mathrm{n}=4, \mathrm{~d}=20, \mathrm{p}^{*}=0.7, \mathrm{a}=0.16, \mathrm{c}=$ $600 .^{9}$ Participants play 40 periods of this game under a partner matching protocol.

\subsection{Theoretical predictions and behavioural assumptions 2.2.1. Theoretical predictions}

In this section we derive predictions from our experimental treatments under the assumptions of common knowledge of rationality, risk neutrality and selfishness. For the three treatments the theoretical prediction is straightforward: for the parameters presented above, if the game consisted of one period, the Pareto solution is for all participants to invest all their tokens in the international public good $X$. By backward induction, the dominant strategy is for a participant to invest all his tokens in insurance $\mathrm{Y}$ (see mathematical proofs in appendix). The same reasoning holds for all of the 40 periods by applying a backward induction mechanism since it is common knowledge for the subjects that the experiment lasts for a finite number of periods.

Assuming common knowledge of rationality and selfishness the opportunity to sanction or reward should not affect the theoretical predictions of the game since both reward and sanction decisions are costly. In the only subgame perfect equilibrium of the game, whether it is played using punishment or reward institution, is for all

\footnotetext{
${ }^{8}$ Assume $S_{i}=Y / d$ to represent the share of investment in $\mathrm{Y}$ for each participant. Then, a more rigorous way to understand the last term of the equation is that it can be alternatively expressed in the following manner: $(1 / n)\left[1-\left(s_{i}-\bar{s}\right)\right] . c$ where $\bar{s}$ represents the average investment share across $n$ participants. Here, our expression tells that the (ex-ante) conditional probability of being hit $(1 / \mathrm{n})$ is multiplied by a rate that is decreasing with the participants' relative effort of investing in national protection $\mathrm{X}$ compared to the average.

${ }_{9}^{9}$ Following a report by CNN (June $22^{\text {nd }}, 2005$ ), the chance of an attack with a weapon of mass destruction somewhere in the world in the next ten years runs as high as $70 \%$, arms experts have predicted in a United States survey. According to the report, four out of five people said that their country was not spending enough on non-proliferation efforts to detect transfer of weapons or materials to terrorism organizations.
} 
players to invest all their endowment in $\mathrm{Y}$ and to never punish (reward). This is stated precisely in $\mathrm{H} 0$.

H0 (Pure Self-Interest and Profit Maximizing). Assuming common knowledge of rationality and selfishness all participants will never invest in the group account (global security) and choose to invest in their own personal security $(Y)$. The opportunity to reward/sanction other group members should not affect the theoretical predictions of the game.

\subsubsection{Behavioural assumptions}

Several studies have shown that many people are reciprocally motivated and sacrifice a part of their payoffs in order to punish bad intentions or reward kind actions (for modeling of reciprocity see Rabin, 1993; Charness and Rabin, 2002; Falk and Fischbacher, 2006; Dufwenberg and Kirchsteiger, 2004). ${ }^{10}$ In the absence of punishment (reward) opportunities, the only way to reciprocate in a VCM is for the player to reduce her own contribution to the group account (See Keser and van Winder, 2002). In contrast introducing institutions that allow sanctioning and rewarding of others should provide a direct way for reciprocally motivated people to reciprocate without changing their own contribution level. For this reason one should expect higher contribution to the group account in the treatments with institutions that allow direct way to deter free riding. ${ }^{11}$ One might thus relax some of the above assumptions and assume that in addition to the purely selfish subjects there may be also a fraction of the players who are reciprocators.

In addition to reciprocity, repeated interactions may also give rise to the possibility of reputation effects. Indeed selfish participants may also have incentives to imitate the reciprocal players by punishing (rewarding) free riders (cooperators) because they can also benefit till the $n-1$ period from an increase of contribution from all members. The intuition is that participants have incentive to build up a reputation as reciprocal players because they anticipate that other players will condition their contribution on expectation of sanction (reward). As a consequence, cooperation in the global security policy should be higher in the sanction and reward treatments than in the baseline

\footnotetext{
10 Reciprocal behaviour was reported in different experimental games. For example, Berg, Dickhaut and McCabe (1995) observe reciprocal decisions in the context of investment game; Gächter and Falk, (2002) in a gift exchange game; Clark and Sefton (2001) in a sequential prisoner's dilemma; Abbink, Irlenbusch and Renner (2000) in the "moonlighting game"., Keser and van Winden (2000) Fehr and Gaechter (2000) Croson (2007) observe that some subjects reciprocate others' contribution to a public good.

${ }^{11}$ Note that it is nearly impossible to obtain precise and quantitative theoretical predictions based on the assumptions presented above. The first reason is that it may be the case that there are some reciprocal people whose preferences are not completely captured by those induced in the experiment or involve players with bounded rationality (Gächter and Falk, 2002; Selten, 1978; Selten and Stoecker, 1986). Second models including reciprocity and reputation usually rely on the condition that a fraction of reciprocal subjects is necessary to allow the emergence of reputation for the majority of rational and selfish players. However these conditions are not necessarily met since depending on the parameters of the experiment the fraction of reciprocal subjects may be quite high. Finally reputation mechanisms generally rely on the assumption that agents enter the experiment with initial belief about the fraction of reciprocal players and update their beliefs over time. However such learning effects make it again more difficult to predict the expected outcome since it should change over time as soon as agents update their beliefs. For all these reasons, only some qualitative conjectures are possible.
} 
treatment. The alternative conjecture to $\mathrm{H} 0$ assuming that there may be a fraction of reciprocal agents is stated precisely in $\mathrm{H} 1$.

H1(Reciprocity and Reputation) the opportunity to reward and sanction other group members may provide a direct way for people who are reciprocally motivated to reciprocate, which should improve cooperation.

In our experimental design participants are not allowed to observe individual reward (sanction) decisions, which should prevent revenge effects. However we cannot rule out the possibility of blind revenge (blind reward) and that such blind decisions may affect current punishment (reward) decisions. Furthermore our design cannot rule out the possibility that some sanction (reward) decisions may be conditional on players' expectations about the decisions by the other group members (Zizzo, 2003). Such effect may be exacerbated in the reward treatment where a subject may have strong incentives to reward someone else if she expects reward from this other participants since reward induce a significant increase in outcome compared to its cost.

$\mathrm{H} 2$ : Both reward and punishing decisions may induce reciprocal behaviours on the rewarding (punishing) decisions, even in absence of possibility to identify precisely the punisher (rewarder). Due to the positive externalities generated by the rewarding mechanism, one might expect that such effects may be higher in the reward treatment.

One can also relax risk neutrality assumption. Most risk lover countries should prefer investing in $\mathrm{z}$ rather than investing in security. Additionally, perception of risk may also affect individual decisions. In particular, one might argue that having experienced a terrorist attack in the past may influence perceptions of risk of future attacks, which is obviously theoretically incorrect since past events do not change the probability that similar event will occur in the future. For example, after September 11, 2001, terrorism has changed risk perceptions, favouring the idea that anything can happen at any time (e.g Bosman and van Winden, 2005). One reason is that people's attention may be focussed mainly on the bad outcome itself and neglect the fact that such event is very unlikely to occur. This effect is generally termed "probability neglect" effect. The idea is that, "when intense emotions are engaged, people tend to focus on the adverse outcome, not on its likelihood," which may lead to significant distortions in both private and public policy" (Sunstein, 2002 p.61). Moreover people may feel a disproportionate fear of risks when risks is hard to control (Slovic, 2000; Sunstein, 2002). Finally, the occurrence of a terrorist attack may also induce an opposite effect, by inciting people to underestimate future terrorist attacks. This effect, generally termed "Gambler fallacy" or "Monte Carlo fallacy", relies on the idea that a certain random event is less likely to happen following an event or a series of events, which is obviously incorrect since past events do not change the probability that similar event will occur in the future. According to Tversky and Kahneman gambler's fallacy may be induced by a psychological heuristic. ${ }^{12}$ This is stated in $\mathrm{H} 3$.

H3: Risk may influence decisions in several ways. First it may influence investments on $\mathrm{z}$ since the more risk lover countries should opt for alternative policies rather than

\footnotetext{
${ }^{12}$ The intuition behind Gambler Fallacy is that people may expect that deviations from average should balance out. For example, if a fair coin is tossed repeatedly and tails comes up a larger number of times than is expected, a gambler may incorrectly believe that this means that heads is more likely in future tosses. Such an event is often referred to as being "due.
} 
investing in security. Second, previous terrorist attacks may also influence perceptions of risk and therefore influence current decisions.

Note however that the global effect of perception of risk is indeterminate, leaving it to empirical analysis to identify links between investment decisions and risk perception.

\subsection{Treatments}

For all treatments, the participants were given two Tables. A first Table (see Table 1a) gives the probability of an international attack for each total amount of tokens invested in $X$ by all the participants. The second Table (see Table 1b) gives the conditional probability that a specific participant will be hit if an attack occurs according to her/his investment in the private "insurance" good, $Y$, aimed essentially to protect herself, and the contributions of the others members of his group. A participant investing more in $Y$ (less) than the average of the other members of the group reduces (increases) her probability of being hit. The probability of being hit conditional on an attack occurring is equal for all the members if all the individuals invest exactly the same amount on $Y$.

Table 1a. Probability of occurrence of an attack for each number of tokens invested in X by the group

\begin{tabular}{|c|c|c|c|c|c|}
\hline $\begin{array}{l}\text { Number of tokens } \\
\text { invested in } X \text { by } \\
\text { the all group }\end{array}$ & $\begin{array}{c}\text { Probability of } \\
\text { occurrence of an } \\
\text { attack }\end{array}$ & $\begin{array}{c}\text { Number of tokens } \\
\text { invested in } X \text { by the } \\
\text { all group }\end{array}$ & $\begin{array}{l}\text { Probability } \\
\text { of an attack }\end{array}$ & $\begin{array}{c}\text { Number of tokens } \\
\text { invested in } X \text { by } \\
\text { the group }\end{array}$ & $\begin{array}{c}\text { Probability of } \\
\text { occurrence of an } \\
\text { attack }\end{array}$ \\
\hline 0 & $70.00 \%$ & 28 & $64.40 \%$ & 56 & $58,80 \%$ \\
\hline 1 & $69.80 \%$ & 29 & $64.20 \%$ & 57 & $58,60 \%$ \\
\hline 2 & $69.60 \%$ & 30 & $64.00 \%$ & 58 & $58,40 \%$ \\
\hline 3 & $69.40 \%$ & 31 & $63.80 \%$ & 59 & $58,20 \%$ \\
\hline 4 & $69.20 \%$ & 32 & $63.60 \%$ & 60 & $58,00 \%$ \\
\hline 5 & $69.00 \%$ & 33 & $63.40 \%$ & 61 & $57,80 \%$ \\
\hline 6 & $68.80 \%$ & 34 & $63.20 \%$ & 62 & $57,60 \%$ \\
\hline 7 & $68.60 \%$ & 35 & $63.00 \%$ & 63 & $57,40 \%$ \\
\hline 8 & $68.40 \%$ & 36 & $62.80 \%$ & 64 & $57,20 \%$ \\
\hline 9 & $68.20 \%$ & 37 & $62.60 \%$ & 65 & $57,00 \%$ \\
\hline 10 & $68.00 \%$ & 38 & $62.40 \%$ & 66 & $56,80 \%$ \\
\hline 11 & $67.80 \%$ & 39 & $62.20 \%$ & 67 & $56,60 \%$ \\
\hline 12 & $67.60 \%$ & 40 & $62.00 \%$ & 68 & $56,40 \%$ \\
\hline 13 & $67.40 \%$ & 41 & $61.80 \%$ & 69 & $56,20 \%$ \\
\hline 14 & $67.20 \%$ & 42 & $61.60 \%$ & 70 & $56,00 \%$ \\
\hline 15 & $67.00 \%$ & 43 & $61.40 \%$ & 71 & $55,80 \%$ \\
\hline 16 & $66.80 \%$ & 44 & $61.20 \%$ & 72 & $55,60 \%$ \\
\hline 17 & $66.60 \%$ & 45 & $61.00 \%$ & 73 & $55,40 \%$ \\
\hline 18 & $66.40 \%$ & 46 & $60.80 \%$ & 74 & $55,20 \%$ \\
\hline 19 & $66.20 \%$ & 47 & $60.60 \%$ & 75 & $55,00 \%$ \\
\hline 20 & $66.00 \%$ & 48 & $60.40 \%$ & 76 & $54,80 \%$ \\
\hline 21 & $65.80 \%$ & 49 & $60.20 \%$ & 77 & $54,60 \%$ \\
\hline 22 & $65.60 \%$ & 50 & $60.00 \%$ & 78 & $54,40 \%$ \\
\hline 23 & $65.40 \%$ & 51 & $59.80 \%$ & 79 & $54,20 \%$ \\
\hline 24 & $65.20 \%$ & 52 & $59.60 \%$ & 80 & $54,00 \%$ \\
\hline 25 & $65.00 \%$ & 53 & $59.40 \%$ & & \\
\hline 26 & $64,80 \%$ & 54 & $59,20 \%$ & & \\
\hline 27 & $64,60 \%$ & 55 & $59,00 \%$ & & \\
\hline
\end{tabular}


Table 1b. The probability of being hit conditional on an attack occurring according to his investment in the private "insurance" good, $Y$

\begin{tabular}{|c|c|c|c|}
\hline $\begin{array}{l}\text { Deviation between i's investment } \\
\text { and group average investment on } \\
\text { Y }\end{array}$ & $\begin{array}{l}\text { Probability of } \\
\text { being hit } \\
\text { conditional on an } \\
\text { attack occurring }\end{array}$ & $\begin{array}{l}\text { Deviation between i's } \\
\text { investment and group average } \\
\text { investment on Y }\end{array}$ & $\begin{array}{l}\text { Probability of } \\
\text { being hit } \\
\text { conditional on an } \\
\text { attack occurring }\end{array}$ \\
\hline-15 UME below the average & 0.4375 & 0 & 0.25 \\
\hline-14 UME below the average & 0.425 & 1 UME above the average & 0.2375 \\
\hline-13 UME below the average & 0.4125 & 2 UME above the average & 0.225 \\
\hline-12 UME below the average & 0.4 & 3 UME above the average & 0.2125 \\
\hline-11 UME below the average & 0.3875 & 4 UME above the average & 0.2 \\
\hline-10 UME below the average & 0.375 & 5 UME above the average & 0.1875 \\
\hline-9 UME below the average & 0.3625 & $6 \mathrm{UME}$ above the average & 0.175 \\
\hline$-8 \mathrm{UME}$ below the average & 0.35 & 7 UME above the average & 0.1625 \\
\hline$-7 \mathrm{UME}$ below the average & 0.3375 & $8 \mathrm{UME}$ above the average & 0.15 \\
\hline$-6 \mathrm{UME}$ below the average & 0.325 & 9 UME above the average & 0.1375 \\
\hline-5 UME below the average & 0.3125 & 10 UME above the average & 0.125 \\
\hline-4 UME below the average & 0.3 & $11 \mathrm{UME}$ above the average & 0.1125 \\
\hline-3 UME below the average & 0.2875 & 12 UME above the average & 0.1 \\
\hline-2 UME below the average & 0.275 & 13 UME above the average & 0.0875 \\
\hline \multirow[t]{2}{*}{$-1 \mathrm{UME}$ below the average } & 0.2625 & 14 UME above the average & 0.075 \\
\hline & & 15 UME above the average & 0.0625 \\
\hline
\end{tabular}

The baseline treatment is the one just described above. At the end of each period, the realisation or not of a loss $600 \mathrm{UME}$ is drawn at random following the number of UME invested on $X$ by the group (Table 1a). If a terrorist attack occurs, the probability that a specific individual being hit is drawn at random following the idiosyncratic probability based on the elements of Table $1 \mathrm{~b}$. The gain for each participant at the end of each period of play is determined by his initial endowment of 6000 UME at the beginning of the game adjusted at each period by an amount of 20 UME minus the amounts invested on $X$ and $Y$ and minus the loss of $600 \mathrm{UME}$ if the unfavourable event touches the individual. The final gain corresponds to the endowment of $6000 \mathrm{UME}$ adjusted for the gains or losses at each period.

In the second treatment, called the sanction treatment, we add a second stage in which, each subject, after being informed about each other group member's contribution, can assign 0 to 10 punishment points to any of the other three group members. The last treatment called "reward" treatment is identical to the previous treatment except that assigning points of reward increase the earning of the participants who receive these points. In both reward and sanction treatment, assigning points is costly. The schedule of costs is given in Tables $2 \mathrm{a}$ and $2 \mathrm{~b}$ for the sanction and reward treatments, respectively. ${ }^{13}$

\footnotetext{
13 In contrast to Andreoni et al. (2002), in Sefton et al. (2007) and Walker and Halloran (2004) the cost of a $\$ 1$ cent (sanction) reward is \$1. Note however that as noted by Andreoni et al. (2003) one can find several examples where the cost versus consequence of sanctions and punishment is not one-for-one. For example the cost of imposing a trade embargo is likely to be much smaller than the consequences for the target. Similarly the cost of development assistance and other financial transfers toward less developed countries may be smaller that the benefit for the developing country. For these reasons we chose a cost-consequence ratio superior to 1 .
} 
Table 2a. Levels of punishment and associated costs to the punisher

\begin{tabular}{lccccccccccc}
\hline Punishment Points & 0 & 1 & 2 & 3 & 4 & 5 & 6 & 7 & 8 & 9 & 10 \\
\hline Cost to the punisher in units & 0 & 5 & 10 & 15 & 30 & 45 & 60 & 90 & 100 & 125 & 150 \\
Cost to the target in units & 0 & 20 & 40 & 60 & 120 & 180 & 240 & 360 & 400 & 500 & 600 \\
\hline
\end{tabular}

Table 2b. Levels of reward and associated costs to the rewarder

\begin{tabular}{lccccccccccc}
\hline Reward Points & 0 & 1 & 2 & 3 & 4 & 5 & 6 & 7 & 8 & 9 & 10 \\
\hline Cost to the rewarder in units & 0 & 5 & 10 & 15 & 30 & 45 & 60 & 90 & 100 & 125 & 150 \\
Reward to the target in units & 0 & 20 & 40 & 60 & 120 & 180 & 240 & 360 & 400 & 500 & 600 \\
\hline
\end{tabular}

For these last two treatments, the Pareto solution and the dominant strategy remain the same as in the baseline treatment.

\subsection{Procedures Common to All Treatments}

The experiment consisted of seven sessions. In each session, there were 40 periods of interaction. All of the sessions were conducted at the Center for Research in Economics and Management (CREM), at the University Rennes I, Rennes, France. Between 8 and 16 subjects participated in each session. 80 subjects were recruited from undergraduate courses in business and economics at the university. None of the subjects had participated in an economic experiment previously. No subject participated in more than one session. On average, a session lasted 100 minutes including initial instruction and payment of subjects. The experiment was computerized using the Ztree program developed at the University of Zurich. ${ }^{14}$ Table 3 contains some summary information about each of the sessions. The first column indicates the session number. The second through fourth columns indicate the number of subjects that took part in the session, the number of four-person groups in the session, and the treatment in effect.

Table 3: Characteristics of the Experimental Sessions

\begin{tabular}{|c|c|c|c|}
\hline $\begin{array}{c}\text { Session } \\
\text { Number }\end{array}$ & $\begin{array}{c}\text { Number of } \\
\text { Subjects }\end{array}$ & $\begin{array}{c}\text { Number of } \\
\text { groups }\end{array}$ & Treatment \\
\hline 1 & 12 & 3 & Baseline \\
\hline 2 & 16 & 4 & Baseline \\
\hline 3 & 12 & 3 & Sanction \\
\hline 4 & 8 & 2 & Sanction \\
\hline 5 & 8 & 2 & Sanction \\
\hline 6 & 12 & 3 & Reward \\
\hline 7 & 12 & 3 & Reward \\
\hline
\end{tabular}

A partner matching protocol was in effect for all sessions. The computer network separated the subjects taking part in a session into groups of size four. Group assignments remained fixed for the entire session and the members of a group

${ }^{14}$ See Fischbacher (2007) for a description of the ztree computer program. 
interacted exclusively with their own group members for the entire session. Individuals received no information about the activity of any groups other than their own. There were 40 periods of play in each session. At the beginning of the experiment, the instructions were distributed and read to the subjects. There followed a quiz, consisting of several questions concerning the rules of the game and how earnings are determined, which all subjects were required to answer. The experimenter then announced and explained the correct responses. Subjects could indicate whether they had any questions about the process and the experimenter would answer them in private.

At the end of each session, subjects were asked to fill an individual questionnaire. We also asked them to play a simple lottery choice experiment to determine their degree of risk aversion. This simple game replicates Holt and Laury (2002)'s design with real payoffs. Precisely, subjects were confronted with ten choices between two lotteries, one "risky" (with payoffs of $€ 3.85$ and $€ 0.1$ ) and one "safe" (with payoffs of $€ 2$ and $€ 1.6$ ), with probabilities ranging from $10 \%$ to $100 \%$. As noted by Holt and Laury, the payoffs for the safe lottery (Option A) are less variable than those for the risky lottery (Option B). In both options the probabilities for the first of the ten sequential decisions are $10 \%$ for the high payoff and $90 \%$ for the low payoff. The difference in the expected payoffs between the two lotteries is such that only an extreme risk-seeker would choose Option B. As the probability of the high payoff outcome increases B becomes more attractive relative to $\mathrm{A}$, and at some point subjects will switch their preference. Towards the end of the decision sequence even the most risk averse subjects should switch over to option B.

\section{Results}

\subsection{Determinants of investments in protection in absence of institution}

This section investigates the determinants of investment in the baseline treatment. Figure 1 illustrates the time path of average group contribution in $X$ by period in each treatment. The period number is shown on the horizontal axis and the average group contribution on the vertical axis. The maximum possible group contribution, corresponding to the group optimum, is 80 . The minimum possible contribution is 0 . The average contribution in $X, Y$ and $Z$ for each group of the different treatment are also shown in Table 4, with the standard deviations given in parentheses. 
Figure 1. Evolution of average group investment in $X$ per treatment

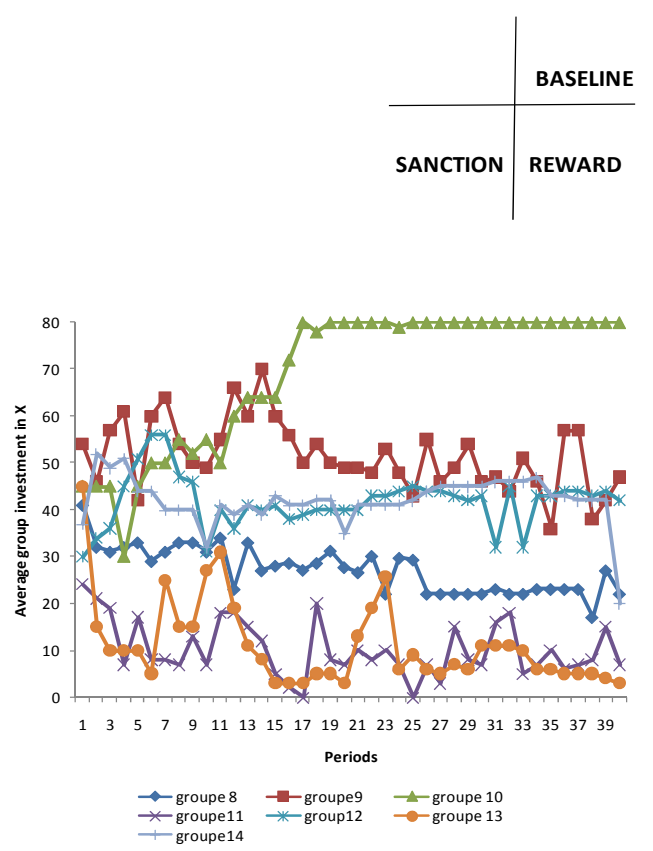

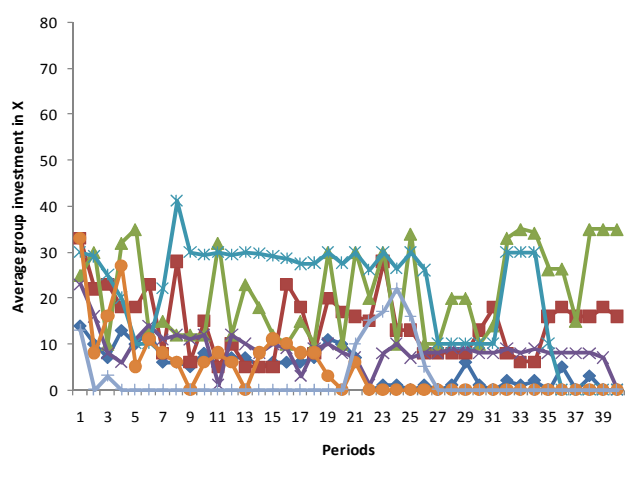
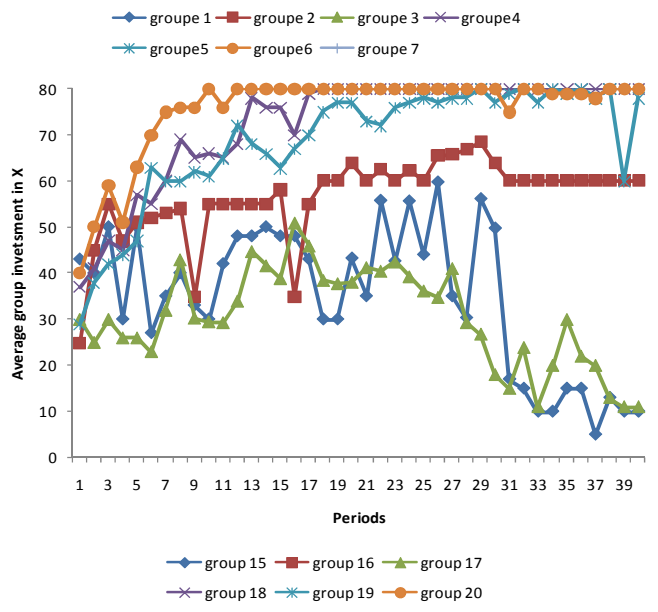

Table 4: Average Group Investment Levels on $X, Y$ and $Z$ per Treatment $(\max =80, \min =0)$

\begin{tabular}{cccccccccc}
\hline & Baseline & \multicolumn{3}{c}{ Sanction } & \multicolumn{3}{c}{ Reward } \\
\hline & $\mathrm{x}$ & $\mathrm{Y}$ & $\mathrm{Z}$ & $\mathrm{X}$ & $\mathrm{y}$ & $\mathrm{Z}$ & $\mathrm{x}$ & $\mathrm{y}$ & $\mathrm{Z}$ \\
\hline Group 1 & 4.82 & 45.32 & 29.85 & 25.45 & 50.05 & 4.5 & 32.4 & 29.6 & 18 \\
& $(4.11)$ & $(12.63)$ & $(10.75)$ & $(5.42)$ & $(9.09)$ & $(5.41)$ & $(13.71)$ & $(9.68)$ & $(8.44)$ \\
Group 2 & 14.45 & 56.37 & 9.17 & 51.57 & 24.92 & 3.5 & 55.42 & 23.82 & 0.75 \\
& $(7.09)$ & $(11.69)$ & $(7.31)$ & $(7.31)$ & $(6.83)$ & $(6.01)$ & $(7.86)$ & $(6.93)$ & $(2.39)$ \\
Group 3 & 21.87 & 45.82 & 12.3 & 69.07 & 7.27 & 3.65 & 25.07 & 37.8 & 17.12 \\
& $(10.35)$ & $(10.27)$ & $(10.55)$ & $(14.70)$ & $(10.39)$ & $(5.03)$ & $(9.30)$ & $(10.40)$ & $(9.16)$ \\
Group 4 & 8.8 & 67.65 & 3.55 & 10.25 & 46.8 & 22.95 & 72.35 & 7.15 & 0.5 \\
& $(3.85)$ & $(6.17)$ & $(3.34)$ & $(5.83)$ & $(7.75)$ & $(7.59)$ & $(12.22)$ & $(11.78)$ & $(0.77)$ \\
Group 5 & 22.11 & 43.47 & 14.42 & 41.75 & 28.5 & 9.85 & 68.5 & 10.17 & 1.32 \\
& $(11.99)$ & $(13.55)$ & $(8.11)$ & $(5.54)$ & $(5.11$ & $(5.44)$ & $(12.89)$ & $(10.39)$ & $(3.34)$ \\
Group 6 & 4.7 & 57.97 & 17.32 & 10.95 & 40.77 & 28.27 & 75.65 & 4 & 0.35 \\
& $(7.25)$ & $(8.53)$ & $(5.61)$ & $(8.81)$ & $(13.37)$ & $(11.21)$ & $(9.41)$ & $(8.64)$ & $(0.88)$ \\
Group 7 & 2.52 & 55.4 & 22.07 & 42 & 27.85 & 10.15 & & & \\
& $(5.72)$ & $(6.94)$ & $(7.06)$ & $(5.13)$ & $(7.05)$ & $(6.48)$ & & & \\
\hline Average & $\mathbf{1 1 . 3 2}$ & $\mathbf{5 3 . 1 4}$ & $\mathbf{1 5 . 5 2}$ & $\mathbf{3 5 . 8 6}$ & $\mathbf{3 2 . 3 1}$ & $\mathbf{1 1 . 8 3}$ & $\mathbf{5 4 . 8 9}$ & $\mathbf{1 8 . 7 5}$ & $\mathbf{6 . 3 4}$ \\
Std. Dev. & $\mathbf{( 7 . 1 9 )}$ & $\mathbf{( 9 . 9 6 )}$ & $\mathbf{( 7 . 5 3 )}$ & $\mathbf{( 7 . 5 3 )}$ & $\mathbf{( 9 . 0 8 )}$ & $\mathbf{( 6 . 7 3 )}$ & $\mathbf{( 1 0 . 8 9 )}$ & $\mathbf{( 9 . 6 3 )}$ & $\mathbf{( 4 . 1 6 )}$ \\
\hline
\end{tabular}


Both Table 4 and Figure 1 show that, in the baseline treatment, subjects contribute very low level of their initial endowment to the group account X (11.32\%). Figure 1 shows that the average contribution level declines over time in the baseline treatment to reach a very low level of contribution at the end of the game. This result is in line with a number of other experiments, which have documented that contributions in classical VCM tend to decline with repetition (Isaac et al. 1984, Isaac and Walker, 1988, Andreoni, 1988).

These results clearly indicate that, in absence of institutional incentives, people choose to defect and adopt an opportunist behavior by protecting themselves or investing in alternative policies instead of contributing to a collective protection that would be more optimal to reduce the probability of an attack. Our observations regarding contribution levels in the baseline treatment are described as result 1 below.

Result 1: In absence of external institutional incentives, people fail to coordinate on a collective protection policy and choose to defect by investing in their own security (i.e. Y). Furthermore only the most risk loving participants choose to invest in z.

Support for result 1. To further explore the determinants of investments in X, Y and $Z$, we estimate the determinants of investment via random effects Tobit models. The use of Random Effect Tobit models is justified by the panel dimension of our data and the number of censored observations in the sample. Table 5 contains the estimates from the following regression model:

$$
\text { Invest }_{i, t}=\beta_{0}+\beta_{1} \sum_{j=1 ; j \neq i}^{n-1} \text { Invest }_{-i ; t-1}+\beta_{2} \text { Loss }_{t-1} \beta_{3} t+\beta_{4} \text { finalt }+\beta_{5} W
$$

The dependent variable "invest ${ }_{i t}$ " is player i's investment in period t in $X, Y$ and $Z$, respectively from the left to the right part of Table 5. Column (1) reports estimates on the determinants of investment to the group account $\mathrm{x}$. The independent variables include several dummy variables that are expected to be relevant. The variable "Loss in $t-1$ " takes the value 1 if the individual has been hit by an attack in t-1 and 0 otherwise. This variable seeks to capture how previous attacks might affect current decisions. The variable "Final period" takes the value 1 for the last period of the game and 0 otherwise. The independent variable "Sum investments of others in period $t-1$ " takes the value of total contribution of the group to the group account in previous period. The second econometric specification controls the previous results with the addition of demographic variables including gender, education and risk aversion. In our experiment degree of risk aversion was captured by the total number of "safe" lottery choices made by participants in the lottery choice experiment. Precisely participants are risk averse when they choose at least five times lottery A before switching to B. 
Table 5: Determinants of Investments in $X, Y$ and $Z$ in the Baseline treatment

\begin{tabular}{|c|c|c|c|c|c|c|}
\hline \multirow{2}{*}{$\begin{array}{l}\text { Dep. variable } \\
\text { Models } \\
\text { treat. }\end{array}$} & \multicolumn{2}{|c|}{ Indiv invest. in $\mathrm{x}$} & \multicolumn{2}{|c|}{ Indiv invest. in y } & \multicolumn{2}{|c|}{ Indiv invest. on $\mathrm{z}$} \\
\hline & $\begin{array}{c}\text { RE Tobit }^{\mathrm{a}} \\
\text { Baseline } \\
(1)\end{array}$ & $\begin{array}{c}\text { RE Tobit } \\
\text { Baseline } \\
(2) \\
\end{array}$ & $\begin{array}{c}\text { RE Tobit }^{\mathrm{a}} \\
\text { Baseline } \\
\text { (3) }\end{array}$ & $\begin{array}{c}\text { RE Tobit }^{\mathrm{a}} \\
\text { Baseline } \\
(4) \\
\end{array}$ & $\begin{array}{c}\text { RE Tobit }^{\mathrm{a}} \\
\text { Baseline } \\
(5) \\
\end{array}$ & $\begin{array}{c}\text { RE Tobit }{ }^{\mathrm{a}} \\
\text { Baseline } \\
(6) \\
\end{array}$ \\
\hline $\begin{array}{l}\text { Sum of invest. } \\
\text { of others in } \\
\text { X(lagged) }\end{array}$ & $\begin{array}{l}0.157 * * * \\
(0.048)\end{array}$ & $\begin{array}{l}0.171 * * * \\
(0.054)\end{array}$ & $\begin{array}{l}-0.106^{* * *} \\
(0.036)\end{array}$ & $\begin{array}{l}-0.106^{* * *} \\
(0.036)\end{array}$ & $\begin{array}{l}-0.008 \\
(0.045)\end{array}$ & $\begin{array}{l}-0.009 \\
(0.045)\end{array}$ \\
\hline Loss (lagged) & $\begin{array}{l}1.284 * \\
(0.738)\end{array}$ & $\begin{array}{l}1.562 * \\
(0.839)\end{array}$ & $\begin{array}{l}1.058^{*} \\
(0.570)\end{array}$ & $\begin{array}{l}1.058^{*} \\
(0.570)\end{array}$ & $\begin{array}{l}-2.832 * * * \\
(0.671)\end{array}$ & $\begin{array}{l}-2.835^{* * * *} \\
(0.672)\end{array}$ \\
\hline Period & $\begin{array}{l}-0.113^{* * * *} \\
(0.034)\end{array}$ & $\begin{array}{l}-0.121 * * * \\
(0.038)\end{array}$ & $\begin{array}{l}0.187 * * * \\
(0.025)\end{array}$ & $\begin{array}{l}0.187 * * * \\
(0.025)\end{array}$ & $\begin{array}{l}-0.225^{* * * *} \\
(0.030)\end{array}$ & $\begin{array}{l}-0.225^{* * *} \\
(0.030)\end{array}$ \\
\hline $\begin{array}{l}\text { Final period } \\
\text { Risk aversion }\end{array}$ & $\begin{array}{l}-1.188 \\
(1.114)\end{array}$ & $\begin{array}{l}-1.502 \\
(1.262) \\
1.954 \\
(1.525)\end{array}$ & $\begin{array}{l}0.169 \\
(0.791)\end{array}$ & $\begin{array}{l}0.169 \\
(0.791) \\
0.181 \\
(1.711)\end{array}$ & $\begin{array}{l}0.720 \\
(0.940)\end{array}$ & $\begin{array}{l}0.718 \\
(0.940) \\
-2.762 * \\
(1.607)\end{array}$ \\
\hline Demographics & no & Yes & no & yes & no & Yes \\
\hline Constant & $\begin{array}{l}-5.326^{* *} \\
(2.395)\end{array}$ & $\begin{array}{l}-13.861 * \\
(8.308)\end{array}$ & $\begin{array}{l}14.347 * * * \\
(2.581)\end{array}$ & $\begin{array}{l}13.243 \\
(9.208) \\
\end{array}$ & $\begin{array}{l}1.297 \\
(2.703) \\
\end{array}$ & $\begin{array}{l}12.579 \\
(8.796) \\
\end{array}$ \\
\hline $\begin{array}{l}\text { Observations } \\
\text { Log likelihood } \\
\text { Wald chi2 } \\
\text { Left censored obs. } \\
\text { Right censored obs. }\end{array}$ & $\begin{array}{c}1092 \\
-1464.83 \\
37.86 \\
731\end{array}$ & $\begin{array}{c}1092 \\
-1405.73 \\
144.37 \\
731\end{array}$ & $\begin{array}{c}1092 \\
-2144.44 \\
111.63 \\
124 \\
393\end{array}$ & $\begin{array}{c}1092 \\
-2144.04 \\
306.40 \\
124 \\
393\end{array}$ & $\begin{array}{c}1092 \\
-1636.80 \\
89.18 \\
602 \\
68\end{array}$ & $\begin{array}{c}1092 \\
-1634.95 \\
316.95 \\
602 \\
68\end{array}$ \\
\hline $\begin{array}{l}\text { Notes: }{ }^{\text {a }} \text { RE Tobit }=\text { Ran } \\
\text { Standard errors in pare } \\
\text { that takes the value } 1 \text { if } \\
\text { hit by a terrorist attac } \\
\text { participant in the lotter } \\
\text { except participant i. Der }\end{array}$ & $\begin{array}{l}\text { om Effect Tc } \\
\text { heses. Period } \\
\text { eriod equals } \\
\text { and } 0 \text { other }\end{array}$ & tesponds & for gende & $\begin{array}{l}\text { vel; ** at the } \\
-40) \text { of the ga } \\
\text { y variable wh }\end{array}$ & $\begin{array}{l}5 \text { level; * at } \\
\text { Final period } \\
\text { is } 1 \text { when the } \\
\text { A lotteries c }\end{array}$ & $\begin{array}{l}\text { ee } 0.1 \text { level; } \\
\text { is a dummy } \\
\text { articipant is } \\
\text { osen by the } \\
\text { up members }\end{array}$ \\
\hline
\end{tabular}

Column (1) shows that participants' contribution in $\mathrm{X}$ is significantly and positively influenced by the contributions of others in the previous period. The positive and significant coefficient associated to the variable "loss (lagged)" indicates that people tend to contribute more for their protection by investing in $\mathrm{X}$ after being hit in previous period. This result is consistent both with the idea that people overreact when risks appear unfamiliar and hard to control (Slovic, 2000; Sunstein, 2002) and with "probability neglect" theory (Sunstein, 2002).

Turning next to the determinants of the investments in the private insurance $Y$ reported in columns (3) and (4), we find that observing high contribution in $\mathrm{x}$ from the other group members incite participants to reduce their investment in $Y$. As found for investments in $\mathrm{x}$, we also find that people invest more in $\mathrm{y}$ (i.e. for their own protection) after being hit by an attack.

Finally, columns (5) and (6) provide results concerning the determinants of investments in $Z$. A negative and significant coefficient associated to the variable "loss (lagged)" indicates that people invest less in $\mathrm{z}$ after an attack. It is interesting to notice that including demographic variables in specifications do not affect the experimental variables' estimated coefficients. Demographics are not significant except "risk aversion" variable that attracts a negative and significant coefficient in estimate (6) showing that the more risk averse people are less likely to invest in z. 
One average risk averse people contribute only 3.57 units in $\mathrm{z}$ while more risk lover participants contribute 4.28 units. This result is consistent with previous findings indicating that a part of the defection in collective policies against terrorism may be explained by the fact that countries may perceive threat of terrorism differently and that only the most risk averse countries would invest to deter terrorism (Sandler and Enders, 2004).

\subsection{The effects of sanctions and rewards on investments in protection}

This section investigates the effects of rewarding and sanctioning mechanisms on cooperation in collective anti-terrorist policy. Figure 1 shows the time series of the average group contributions in $\mathrm{X}$ for each group in the baseline, sanction and reward treatments, respectively. Figure 1 illustrates the existence of strong heterogeneity among groups in the sanction treatment. Some groups seem to be influenced by sanctions and tend to invest more in $X$. In contrast, some other groups seem to be less influenced by punishment and invest rather low levels of contribution in $X$. Figure 1 shows a rather different picture for the reward treatment. Indeed 4 of 6 groups seem to be significantly and positively influenced by rewards, while the two others groups react to rewards only at the beginning of the game. Table 4 also shows this heterogeneity between groups. In addition, In addition figures 2 illustrates the time path of aggregate average group investments by period and by treatment in $X, Y$ and $Z$, respectively.

\section{Figure 2. Average group invest. per treatment}
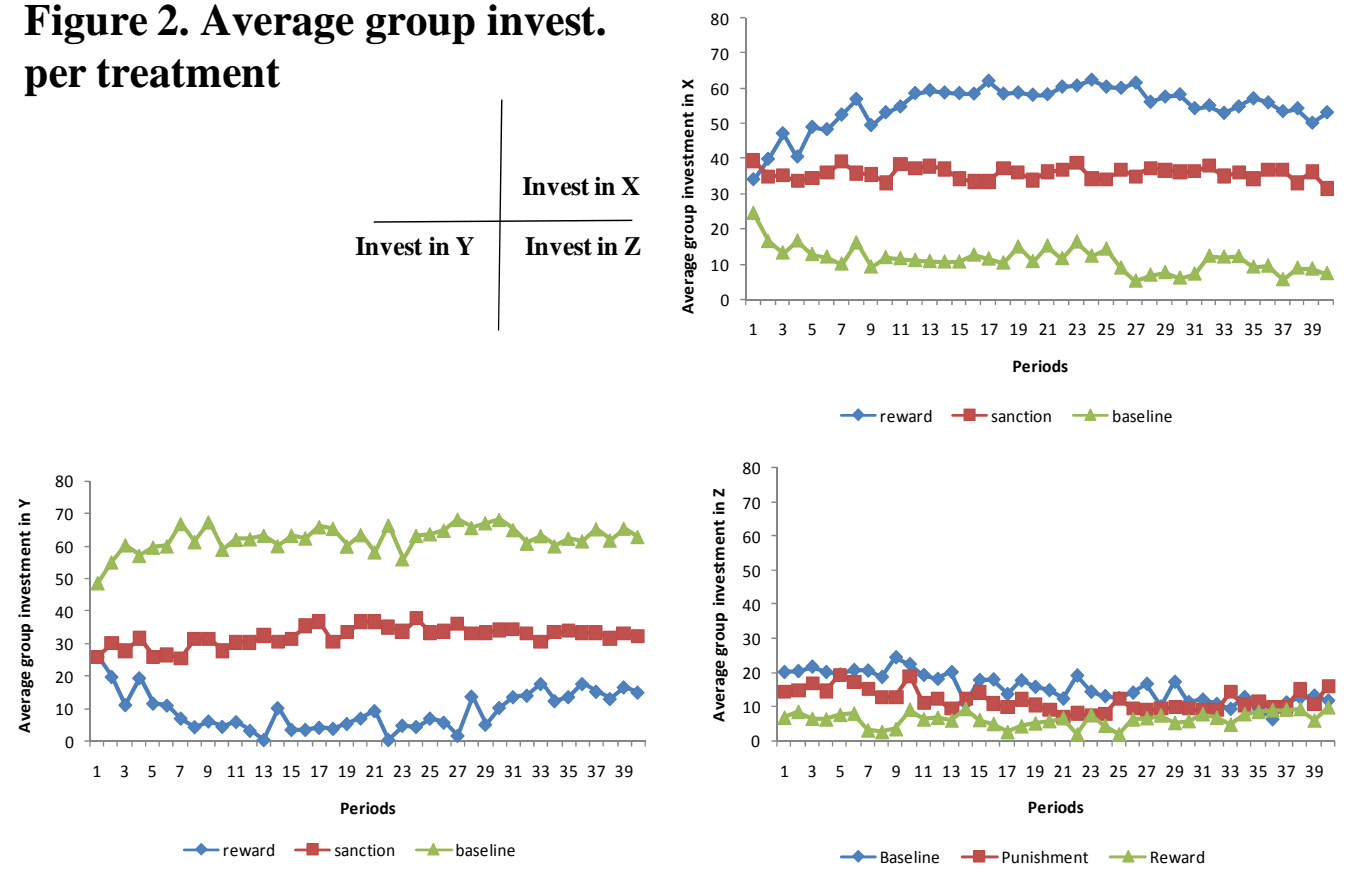

Table 6 shows the distribution of investments in $X$ and $Y$ by treatment. Overall the average investment in $X$ is highest in the reward treatment (54.89) per group from a possible maximum of 80 , followed in turn by the punishment treatment (35.86) and the baseline treatment (11.32). In the reward treatment, 3 of 6 groups contribute more than $80 \%$ of their endowment over the 40 periods, while no group in the baseline treatment does so. In the punishment treatment, 3 of 7 groups contribute more than $60 \%$ of their group endowment. In contrast, we observe an initial increase in the first 
few periods for the baseline with the level of contribution rapidly stabilizing at a rather high level as the game is repeated. Finally, figure 2 shows that the level of investment in $\mathrm{X}$ does not change appreciably in the punishment treatment as the game is repeated, remaining at an intermediate level between the reward and the baseline treatments. Turning next to the investments in $Y$, figure 2 indicates that investments in own protection are significantly higher in the baseline treatment compared to the other treatments. Finally, figure 2 shows that investments in $\mathrm{Z}$ are also influenced at a lower degree by the introduction of an incentive mechanism. These results suggest that introducing incentives systems affect all investments decisions including investments in protection and in alternative projects. The effects of punishment and reward on investments are summarized in Result 2.

Table 6: Distribution of investments in $X, Y$ and $Z$ by treatment.

\begin{tabular}{|c|c|c|c|c|c|c|c|c|c|}
\hline \multirow[b]{2}{*}{ contribution } & \multicolumn{3}{|c|}{ Base } & \multicolumn{3}{|c|}{ Sanction } & \multicolumn{3}{|c|}{ Reward } \\
\hline & $\mathrm{X}$ & $\mathrm{Y}$ & $\mathrm{Z}$ & $\mathrm{X}$ & $\mathrm{Y}$ & $\mathrm{Z}$ & $X$ & $\mathrm{Y}$ & $\mathrm{Z}$ \\
\hline 0 & $66.07 \%$ & $11.43 \%$ & $54.64 \%$ & $15.71 \%$ & $20.98 \%$ & $59.73 \%$ & $13.44 \%$ & $52.81 \%$ & $78.23 \%$ \\
\hline 1 & $3.93 \%$ & $0.63 \%$ & $3.66 \%$ & $2.50 \%$ & $0.71 \%$ & $3.04 \%$ & $2.60 \%$ & $3.96 \%$ & $5.73 \%$ \\
\hline 2 & $2.32 \%$ & $0.45 \%$ & $4.82 \%$ & $2.23 \%$ & $0.89 \%$ & $4.29 \%$ & $0.63 \%$ & $2.81 \%$ & $1.67 \%$ \\
\hline 3 & $0.63 \%$ & $0.36 \%$ & $1.16 \%$ & $2.59 \%$ & $0.54 \%$ & $1.88 \%$ & $0.10 \%$ & $0.83 \%$ & $0.10 \%$ \\
\hline 4 & $0.89 \%$ & $0.63 \%$ & $3.57 \%$ & $0.71 \%$ & $1.79 \%$ & $2.41 \%$ & $0.31 \%$ & $1.35 \%$ & $0.21 \%$ \\
\hline 5 & $4.20 \%$ & $3.93 \%$ & $5.71 \%$ & $7.77 \%$ & $10.89 \%$ & $7.59 \%$ & $5.31 \%$ & $6.15 \%$ & $4.90 \%$ \\
\hline 6 & $1.61 \%$ & $1.79 \%$ & $1.96 \%$ & $4.73 \%$ & $3.84 \%$ & $2.32 \%$ & $0.21 \%$ & $1.25 \%$ & $0.31 \%$ \\
\hline 7 & $1.79 \%$ & $0.89 \%$ & $1.70 \%$ & $2.14 \%$ & $3.66 \%$ & $1.88 \%$ & $0.73 \%$ & $1.04 \%$ & $0.52 \%$ \\
\hline 8 & $3.84 \%$ & $1.34 \%$ & $2.05 \%$ & $3.04 \%$ & $7.23 \%$ & $1.96 \%$ & $1.46 \%$ & $1.67 \%$ & $0.21 \%$ \\
\hline 9 & $0.18 \%$ & $0.80 \%$ & $2.32 \%$ & $2.41 \%$ & $6.96 \%$ & $0.89 \%$ & $0.63 \%$ & $4.38 \%$ & $0.10 \%$ \\
\hline 10 & $8.93 \%$ & $14.02 \%$ & $7.14 \%$ & $22.23 \%$ & $16.07 \%$ & $6.88 \%$ & $9.38 \%$ & $6.88 \%$ & $3.75 \%$ \\
\hline 11 & $0.09 \%$ & $2.59 \%$ & $0.54 \%$ & $6.52 \%$ & $1.61 \%$ & $0.27 \%$ & $2.19 \%$ & $0.10 \%$ & \\
\hline 12 & $0.09 \%$ & $4.73 \%$ & $0.54 \%$ & $4.91 \%$ & $4.02 \%$ & $2.59 \%$ & $1.46 \%$ & $1.67 \%$ & $0.21 \%$ \\
\hline 13 & & $2.14 \%$ & $0.36 \%$ & $1.25 \%$ & $1.79 \%$ & $0.09 \%$ & $0.83 \%$ & $1.15 \%$ & \\
\hline 14 & & $1.16 \%$ & $0.98 \%$ & $2.23 \%$ & $3.57 \%$ & $0.09 \%$ & $1.25 \%$ & $0.94 \%$ & $0.10 \%$ \\
\hline 15 & $1.25 \%$ & $6.96 \%$ & $1.70 \%$ & $5.27 \%$ & $5.36 \%$ & $1.34 \%$ & $4.48 \%$ & $4.58 \%$ & $0.42 \%$ \\
\hline 16 & & $3.30 \%$ & $0.45 \%$ & $0.54 \%$ & $0.89 \%$ & & $1.15 \%$ & & \\
\hline 17 & & $1.34 \%$ & $0.09 \%$ & $0.18 \%$ & $0.27 \%$ & $0.09 \%$ & $0.31 \%$ & & $0.10 \%$ \\
\hline 18 & $0.09 \%$ & $4.91 \%$ & $0.36 \%$ & $0.36 \%$ & $1.96 \%$ & & $3.13 \%$ & $0.94 \%$ & $0.52 \%$ \\
\hline 19 & $0.18 \%$ & $1.16 \%$ & $0.09 \%$ & $0.27 \%$ & $1.16 \%$ & & $2.19 \%$ & $0.31 \%$ & $1.46 \%$ \\
\hline 20 & $3.93 \%$ & $35.45 \%$ & $6.16 \%$ & $12.41 \%$ & $5.80 \%$ & $2.68 \%$ & $48.23 \%$ & $7.19 \%$ & $1.46 \%$ \\
\hline
\end{tabular}

Result 2: Introducing sanctions or reward systems significantly increases investments in $X$ (i.e. international protection) and lowers both investments in $Y$ (i.e. national protection) and in $Z$ (investments in alternative projects).

Support for result 2. A Mann-Whitney pairwise statistical test comparing contributions between treatments, maintaining the conservative assumption that each group's activity over the session is a unit of observation shows that the difference in contributions in $X$ between the 
baseline and the punishment treatment is significant at the $p=0.018$ level. ${ }^{15}$ Similarly, contribution in $X$ is significantly higher under the reward treatment compared to the baseline treatment $(p=0.0027)$. Finally, we find that rewards induce higher contribution in $\mathrm{X}$ than punishment. However the difference is not significant $(p=0.15)$. Turning next to the investments in $Y$, we find that they are significantly higher in the baseline treatment compared to the punishment treatment $(p=0.018)$ as well as compared to the reward treatment ( $p$ $=0.0027)$. A borderline significance is found between the reward and the punishment treatments $(p=0.116)$. These findings indicate that introducing reward or sanctions lead the agents to substitute more investments in $X$ compared to $Y$.

Another interesting finding is that rewards and sanctions also affect investments in $Z$. In particular both sanctions and reward incite people to invest significantly less in $Z$. Note, however, that the incidence of incentives systems on $Z$ is lower than its effect on $Y$. A MannWhitney pairwise test indicates that people contribute significantly more in $Z$ in the baseline treatment than in the reward treatment $(p=0.086)$. However, difference between the punishment and baseline treatments is not significant $(p=0.4062)$.

To study in more details how decision-making behaviour of individuals is influenced by rewards and sanctions, we estimated in Table 7 the determinants of contribution levels to the international protection $X$. Columns (1) and (2) display the results of two GLS. Regression (1) controls for variables included in previous estimates presented above in Table 5. Dummy variables "Sanction" and "reward" were included to measure potential treatment effects. These variables are interpreted in relation to the omitted "baseline" treatment. Regression (2) adds two interactions variables "Sum of contribution of others (lagged)*sanction" and "Sum of contribution of others (lagged)*reward". Columns (3) and (4) replicate previous models but using random effects Tobit models to account for both left- and right-censoring. Finally specification (5) includes demographic variables.

15 The unit of observation is the average contribution of the group over the entire session (yielding seven observations per treatment except for the reward treatment with six observations, one per group), and the null hypotheses are that the group contributes an identical amount over a forty-period session. 
Table 7: Determinants of investment in X

\begin{tabular}{|c|c|c|c|c|c|}
\hline $\begin{array}{l}\text { Dep. Var : } \\
\text { Models } \\
\text { Treat. }\end{array}$ & $\begin{array}{l}\text { RE GLS } \\
\text { All treat. } \\
\text { (1) }\end{array}$ & $\begin{array}{c}\text { RE GLS }{ }^{b} \\
\text { All treat. } \\
(2) \\
\end{array}$ & $\begin{array}{l}\text { RE Tobit } \\
\text { All treat. } \\
(3) \\
\end{array}$ & $\begin{array}{c}\text { RE Tobit } \\
\text { All treat. } \\
(4) \\
\end{array}$ & $\begin{array}{c}\text { RE Tobit } \\
\text { All treat. } \\
(5) \\
\end{array}$ \\
\hline Baseline & Ref. & Ref. & Ref. & Ref. & Ref. \\
\hline Reward & $\begin{array}{l}6.608 * * * \\
(1.141)\end{array}$ & $\begin{array}{l}4.735 * * * \\
(1.213)\end{array}$ & $\begin{array}{l}9.234 * * * \\
(2.682)\end{array}$ & $\begin{array}{l}9.754 * * * \\
(2.650)\end{array}$ & $\begin{array}{l}10.094 * * * \\
(2.654)\end{array}$ \\
\hline Sanction & $\begin{array}{l}3.656 * * * \\
(1.077)\end{array}$ & $\begin{array}{l}1.954^{*} \\
(1.131)\end{array}$ & $\begin{array}{l}5.913 * * \\
(2.527)\end{array}$ & $\begin{array}{l}5.630 * * \\
(2.489)\end{array}$ & $\begin{array}{l}5.974 * * \\
(2.492)\end{array}$ \\
\hline Sum of contribution of others (lagged) & $\begin{array}{l}0.138 * * * \\
(0.008)\end{array}$ & $\begin{array}{l}0.053 * * * \\
(0.016)\end{array}$ & $\begin{array}{l}0.183 * * * \\
(0.037)\end{array}$ & $\begin{array}{l}0.183 * * * \\
(0.037)\end{array}$ & $\begin{array}{l}0.183 * * * \\
(0.037)\end{array}$ \\
\hline Loss (lagged) & $\begin{array}{l}0.063 \\
(0.168)\end{array}$ & $\begin{array}{l}0.069 \\
(0.167)\end{array}$ & $\begin{array}{l}0.080 \\
(0.335)\end{array}$ & $\begin{array}{l}0.080 \\
(0.335)\end{array}$ & $\begin{array}{l}-0.511 \\
(0.405)\end{array}$ \\
\hline Loss (lagged)*baseline & & & & & $\begin{array}{l}1.831 * * \\
(0.711)\end{array}$ \\
\hline $\begin{array}{l}\text { Sum of contribution of others (lagged) } \\
* \text { Sanction }\end{array}$ & & $\begin{array}{l}0.121 * * * \\
(0.022)\end{array}$ & $\begin{array}{l}0.114 * * \\
(0.047)\end{array}$ & $\begin{array}{l}0.114 * * \\
(0.047)\end{array}$ & $\begin{array}{l}0.113 * * \\
(0.047)\end{array}$ \\
\hline $\begin{array}{l}\text { Sum of contribution of others (lagged) } \\
* \text { Reward }\end{array}$ & & $\begin{array}{l}0.112 * * * \\
(0.020)\end{array}$ & $\begin{array}{l}0.140 * * * \\
(0.044)\end{array}$ & $\begin{array}{l}0.140 * * * \\
(0.044)\end{array}$ & $\begin{array}{l}0.139 * * * \\
(0.044)\end{array}$ \\
\hline Period & $\begin{array}{l}0.008 \\
(0.007)\end{array}$ & $\begin{array}{l}0.001 \\
(0.007)\end{array}$ & $\begin{array}{l}0.033 * * \\
(0.014)\end{array}$ & $\begin{array}{l}0.033 * * \\
(0.014)\end{array}$ & $\begin{array}{l}0.033 * * \\
(0.014)\end{array}$ \\
\hline Final period & $\begin{array}{l}-0.528 * * \\
(0.215)\end{array}$ & $\begin{array}{l}-0.438 * * \\
(0.215)\end{array}$ & $\begin{array}{l}-1.163 * * * \\
(0.448)\end{array}$ & $\begin{array}{l}-1.162 * * * \\
(0.448)\end{array}$ & $\begin{array}{l}-1.182 * * * \\
(0.447)\end{array}$ \\
\hline Risk aversion & & & & $\begin{array}{l}-0.893 \\
(0.610)\end{array}$ & $\begin{array}{l}-0.895 \\
(0.610)\end{array}$ \\
\hline Demographics & no & no & no & yes & yes \\
\hline Constant & $\begin{array}{l}1.459^{*} \\
(0.768) \\
\end{array}$ & $\begin{array}{l}2.327 * * * \\
(0.769) \\
\end{array}$ & $\begin{array}{l}-6.120 * * * \\
(1.777) \\
\end{array}$ & $\begin{array}{l}-1.276 \\
(3.691) \\
\end{array}$ & $\begin{array}{l}-1.484 \\
(3.692) \\
\end{array}$ \\
\hline Observations & 3120 & 3120 & 3120 & 3120 & 3120 \\
\hline $\begin{array}{l}\text { R2 } \\
\text { Rho }\end{array}$ & $\begin{array}{l}0.50 \\
0.57\end{array}$ & $\begin{array}{l}0.53 \\
0.57\end{array}$ & & & \\
\hline Lef censored obs. & & & 1030 & 1030 & 1030 \\
\hline Right censored obs. & & & 637 & 637 & 637 \\
\hline Log likelihood & & & -5399.88 & -5398.39 & -5395.09 \\
\hline $\begin{array}{l}\text { Notes: }{ }^{\text {a }} \text { RE Tobit=Random Effect Tobit; } \\
\text { level; ** at the } 0.05 \text { level; * at the } 0.1 \text { leve } \\
\text { game. Final period is a dummy that takes } \\
\text { when the participant is hit by a terrorist atta } \\
\text { all group members except participant i. Cos } \\
\text { of received sanction indicates the gain of }\end{array}$ & alue 1 if pe & equals 40 and & $\begin{array}{l}\text { lized Least Squ } \\
\text { riod correspond } \\
\text { otherwise. Lo } \\
\text { tion of others in }\end{array}$ & $\begin{array}{l}\text { ares; *** Signi } \\
\text { to the time per } \\
S \text { is a dummy v } \\
\text { dicates the sum } \\
\text { received by the }\end{array}$ & $\begin{array}{l}\text { cant at the } 0.01 \\
\text { ds }(1-40) \text { of the } \\
\text { iable which is } 1 \\
\text { f contribution of } \\
\text { articipant; Gain }\end{array}$ \\
\hline
\end{tabular}

Table 7 confirms previous findings. It indicates that in all specifications indicating both reward and punishment significantly increase average contribution to the group account $X$. A t test indicates that the effects of rewards are higher than those of punishments. Table 7 also shows that participants are significantly and positively influenced by the levels of contribution of the others in the previous period. Note however that the positive and significant coefficient associated to the interaction variables "Sum of contribution of others (lagged)*sanction" and "Sum of contribution of others (lagged)*reward" shows that the effect of observation of group contribution in previous period is higher under reward and sanction treatment than in the baseline treatment. The variable "Loss (lagged)" is insignificant while the interaction variable "Loss (lagged)*baseline" attracts a positive and significant coefficient, suggesting that having been hit by a terrorist attack in previous period has a positive effect on contribution on $\mathrm{x}$ but only in the baseline treatment. A potential explanation is that contribution decisions in the reward and sanction treatment are mainly driven by received points and by observation of 
contribution of others. Finally, we find that controlling for demographic variables in specification (4) and (5) does not change appreciably the results.

\subsection{The determinants of punishment and reward behaviours}

In stage two of the reward and punishment treatments, agents can observe the contribution decisions of all other individuals, and can condition their sanctioning/rewarding behaviors on this information. Our data indicate that most of people do not sanction others. On average only $14.73 \%$ of people assign one or more points of sanction. Moreover among those who sanction, most of them (74.5\%) assign less than five points. Turning next to reward decisions, we find that in contrast, a large majority of people assign reward points $(57.81 \%)$. More than $25 \%$ of people assign between 8 and 12 reward points. These results are consistent with previous studies that found that people generally prefer using rewards to sanctions (Sefton et al. 2007). One potential reason for this huge number of reward points is that people may condition their reward decisions on expectations that the others will also reward them even if rewarding is anonymous, which in turn translates into higher expected payoffs. In contrast, some players may be reluctant to sanction in order to avoid blind revenge. Another explanation is that rewarding someone may be perceived as more positive action as punishing another participant. Our findings concerning punishing and rewarding decisions are summarized in result 3.

Result3. Both sanction and reward decisions are influenced by deviations from average contribution of others. A non negligible part of these decisions seems to respond to willingness to reciprocate received points in previous period.

Support for result 8: Figure 3 displays the evolution of the average number of punishment and reward points over time. It shows that sanction points decline over time while there is a slight upward trend in the reward points.

Figure 3. Average number of punishment/reward points distributed over time

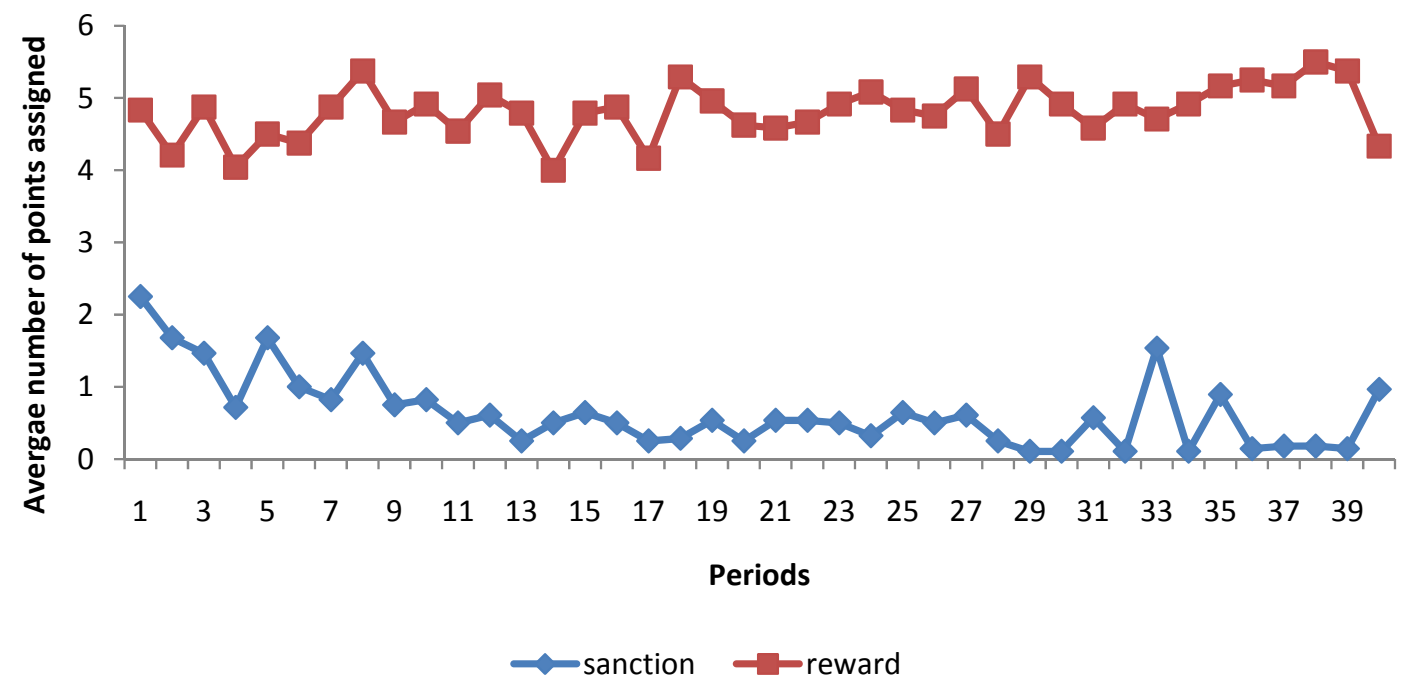

Table 8 shows the results concerning the determinant of sanction decision. It contains the estimates from the following regression model:

$$
p_{i}{ }^{j 2 t}=\beta_{0}+\beta_{1} \bar{c}^{t}+\beta_{2} \max \left\{0,{ }^{t}{ }^{t}-c_{j}{ }^{t}\right\}+\beta_{3} \max \left\{0, c_{j}{ }^{t}-{ }^{-t}\right\}+\beta_{4} \sum \text { recdpoints }{ }_{t-1}+\beta_{5} t+\beta_{6 \mathrm{~W}}
$$


The dependent variable $p_{i}{ }^{j 2 t}$ is the quantity of punishment points that player i assigns to player

$\mathrm{j}$ in the second stage of period $\mathrm{t},{ }^{c_{j}^{t}}$ is player j's contribution in period $\mathrm{t}$, and $\bar{c}_{t}$ is the others' average contribution in period $t$. The variable "received points in $t-1$ " indicates the total number of received points from other members in previous period. The sanction regression results are shown in Table 8 . Table 8 consists of two panels. The left panel displays the results of three regressions in which the dependent variable is the sanction choice of subjects. The right panel, which we will discuss below, presents the results of alternative specifications that check the robustness of the results. The Tobit models account for both left- and rightcensoring. In addition, since each subject is observed a number of times (40 times), we appeal to panel data methods with random effects. A significantly positive coefficient on $\beta 2$ in specifications (1) to (3) indicates that negative deviations from the average contribution on $X$ from others are severely punished. The coefficient associated to the variable "received points in $\mathrm{t}-1$ " is positive and significant, indicating that a part of sanctioning decision can be explained by blind revenge. Note that our design prevented the possibility of direct revenge since players could not observe individual sanctioning decisions across periods. The positive and significant coefficient associated to the "risk aversion » variable indicates that the more risk averse people are those who punish the more. A possible explanation of this result is that this variable captures the fact that risk averse agents may be willing to incite free riders to cooperate more in collective protection and that such expectations may be strongly related to risk aversion. Note that additional estimates (not reported here) indicate that risk aversion variable remains significant even after controlling for player 's contribution. Column (4) shows the marginal effect of each explanatory variable from specification (3).

To check the robustness of our experimental results, we have considered a number of alternative specifications, some of which are reported in the right-hand panel of Table 8 . Previous regressions were based on the strong assumption that decisions to sanction and the choice of sanctioning level are made simultaneously. However it may be in fact important to respect the sequential structure in the sanctioning decisions separating binary decision to sanction from the intensity of punishment. Bearing this in mind, we proceed to an alternative two-step estimation procedure that respects the sequential nature of the decision in order to correct for any selection bias from the exclusion of the observations corresponding to the decisions not to sanction. We therefore ran additional estimations to dissociate the decision to punish from the intensity of punishment. We consider two separable decisions using a two-step estimation procedure: first the decision to sanction someone and second, conditional on the decision to sanction, the choice of the intensity of punishment.

We first estimate the punishment probability using a random effects Probit as a selection equation, producing the inverse of the Mill's ratio (IMR); we then explain the number of points distributed, conditional on the decision to punish, by means of a Generalized Least Squares model corrected for a potential selection bias via the inverse of the Mill's ratio (the "IMR" variable) as an explanatory variable. The exogenous variables in the selection equation include deviations between the target's contribution and the punisher's contributions, "received sanction in t-1" as well as a time trend and demographic variables. Column (5) presents the results from the selection equation and column (6) displays the results of the GLS estimation for the sub-samples of observations in which the subject punishes a group member. The robustness checks deliver the same conclusion as the right-hand panel. 
Table 8: Determinants of punishment

Dep. Variable points of sanction assigned by $\mathrm{i}$ to $\mathrm{j}$

Models

Treatments

Pos. Dev.
from average
Abs. Neg. Dev
from average
Average invest on $\mathrm{x}$
from others
Deviation between
$\mathrm{j}$ and i invest

Received points

(lagged)

Loss (lagged)

Period

First period

final period

Risk aversion

Demographics

Constant
Re Tobit $^{\mathrm{a}}$ RE Tobit ${ }^{\mathrm{a}}$

Sanction

$0.140^{*}$

(0.082)

$0.565 * * *$

(0.073)

0.086

(0.079)

0.143

(0.087)

$0.611 * * *$

$(0.075)$

0.045

(0.085)

\author{
RE Tobit
Sanction
}

(3)

$0.149 *$

(0.087)

$0.614 * * *$

$(0.075)$

0.058

(0.083)

(3)

\begin{tabular}{l}
\multicolumn{1}{c}{$(4)$} \\
0.002 \\
$(0.001)$ \\
$0.009 * * *$ \\
$(0.002)$ \\
0.0001 \\
$(0.001)$
\end{tabular}

Binary decision to sanction

level of

RE Probitc RE GLS

Sanction Sanction

(5) (6)

$-0.096$

(0.091)

$0.286^{* * *}$

(0.066)

-0.120 *

(0.063)

**

$+$

\begin{tabular}{|c|c|c|c|c|c|c|}
\hline \multicolumn{5}{|l|}{$\mathrm{j}$ and $\mathrm{i}$ invest } & \multicolumn{2}{|l|}{$\begin{array}{l}-0.073 * * * \\
(0.009)\end{array}$} \\
\hline Received points & & $0.231 * * *$ & $0.235 * * *$ & $0.003 * *$ & $0.040 * *$ & $0.358 * * *$ \\
\hline (lagged) & & $(0.081)$ & $(0.080)$ & $(0.001)$ & $(0.019)$ & $(0.072)$ \\
\hline \multirow[t]{2}{*}{ Loss (lagged) } & & 0.135 & 0.153 & 0.002 & 0.062 & 0.536 \\
\hline & & $(0.479)$ & $(0.480)$ & $(0.008)$ & $(0.117)$ & $(0.378)$ \\
\hline \multirow[t]{2}{*}{ Period } & $-0.029 * * *$ & $-0.023 * * *$ & $-0.023 * * *$ & $-0.003 * *$ & $-0.007 * * *$ & -0.011 \\
\hline & $(0.009)$ & $(0.008)$ & $(0.008)$ & $(0.0001)$ & $(0.001)$ & $(0.009)$ \\
\hline \multirow[t]{2}{*}{ First period } & 0.650 & 0.262 & 0.266 & 0.004 & & 0.323 \\
\hline & $(0.581)$ & $(0.607)$ & $(0.607)$ & $(0.010)$ & & $(0.509)$ \\
\hline \multirow[t]{2}{*}{ final period } & 0.487 & 0.253 & 0.247 & 0.004 & & -0.161 \\
\hline & $(0.750)$ & $(0.727)$ & $(0.726)$ & $(0.012)$ & & $(0.606)$ \\
\hline \multirow[t]{2}{*}{ Risk aversion } & $1.767 * * *$ & $1.792 * * *$ & $2.157 * * *$ & $0.033 * * *$ & $0.514 * * *$ & $1.733 * * *$ \\
\hline & $(0.534)$ & $(0.563)$ & $(0.575)$ & $(0.009)$ & $(0.152)$ & $(0.584)$ \\
\hline Demographics & & no & yes & yes & yes & Yes \\
\hline \multirow[t]{2}{*}{ Constant } & $-18.067 * * *$ & $-18.289 * * *$ & $-19.624 * * *$ & & $-4.162 * * *$ & $-12.465^{* * *}$ \\
\hline & $(3.106)$ & $(3.277)$ & $(3.242)$ & & $(0.801)$ & $(4.108)$ \\
\hline IMR & & & & & & $\begin{array}{l}3.619 * * * \\
(0.756)\end{array}$ \\
\hline Observations & 3360 & 3276 & 3276 & 3276 & 3276 & 268 \\
\hline $\mathrm{R} 2$ & & & & & & 0.20 \\
\hline Log likelihood & -1230.56 & -1146.62 & -1144.25 & & -566.18 & \\
\hline Left censored obs. & 3075 & 3008 & 3008 & & & \\
\hline
\end{tabular}

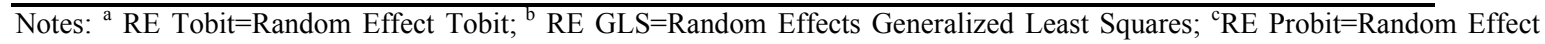
Probit model; *** Significant at the 0.01 level; ** at the 0.05 level; * at the 0.1 level; Standard errors in parentheses. Final period is a dummy that takes the value 1 if period equals 40 and 0 otherwise. Risk aversion corresponds to the number of $\mathrm{A}$ lotteries chosen by the participant in the lottery game. Average invest on $x$ indicates the average of contribution of all group members except participant $\mathrm{j}$. Received sanction indicates the number of points of sanctions received by the participant; Demographics includes dummy variables for gender and for master. "Abs. Neg dev. from average" indicates the absolute value of difference of investment in $\mathrm{x}$ between player $\mathrm{j}$ and average of others if deviation is negative and 0 otherwise. "Pos dev. from average" indicates the value of difference of investment in $\mathrm{x}$ between player $\mathrm{j}$ and average of others if deviation is positive and 0 otherwise. 
Table 9: Determinants of reward decisions

\begin{tabular}{|c|c|c|c|c|c|c|}
\hline Dep. Variable points of $\mathrm{re}$ & ard player i & gns to $\mathrm{j}$ & & & $\begin{array}{l}\text { binary } \\
\text { decision to } \\
\text { reward }\end{array}$ & $\begin{array}{l}\text { level of } \\
\text { reward }\end{array}$ \\
\hline $\begin{array}{l}\text { Model } \\
\text { Treatment }\end{array}$ & $\begin{array}{l}\text { RE Tobita } \\
\text { Reward } \\
\text { (1) }\end{array}$ & $\begin{array}{l}\text { RE Tobita } \\
\text { Reward } \\
\text { (2) } \\
\end{array}$ & $\begin{array}{l}\text { RE Tobita } \\
\text { Reward } \\
\quad(3) \\
\end{array}$ & $\begin{array}{l}\mathrm{dy} / \mathrm{dx} \\
\text { Reward } \\
(4) \\
\end{array}$ & $\begin{array}{l}\text { RE Probitc } \\
\text { Reward } \\
\end{array}$ & $\begin{array}{l}\text { RE GLS } \\
\text { Reward } \\
(6) \\
\end{array}$ \\
\hline $\begin{array}{l}\text { Pos. Dev. from } \\
\text { average }\end{array}$ & $\begin{array}{l}0.154 * * * \\
(0.027)\end{array}$ & $\begin{array}{l}0.168 * * * \\
(0.029)\end{array}$ & $\begin{array}{l}0.168 * * * \\
(0.029)\end{array}$ & $\begin{array}{l}0.014 * * * \\
(0.003)\end{array}$ & & $\begin{array}{l}0.202 * * * \\
(0.023)\end{array}$ \\
\hline $\begin{array}{l}\text { Abs. Neg. Dev from } \\
\text { average }\end{array}$ & $\begin{array}{l}-0.407 * * * \\
(0.017)\end{array}$ & $\begin{array}{l}-0.400 * * * \\
(0.017)\end{array}$ & $\begin{array}{l}-0.400 * * * \\
(0.017)\end{array}$ & $\begin{array}{l}-0.035^{* * *} \\
(0.005)\end{array}$ & & $\begin{array}{l}-0.095 * * * \\
(0.017)\end{array}$ \\
\hline $\begin{array}{l}\text { Average invest on } \mathrm{x} \text { of } \\
\text { others }\end{array}$ & $\begin{array}{l}0.295 * * * \\
(0.031)\end{array}$ & $\begin{array}{l}0.295 * * * \\
(0.034)\end{array}$ & $\begin{array}{l}0.295 * * * \\
(0.034)\end{array}$ & $\begin{array}{l}0.026^{* * *} \\
(0.004)\end{array}$ & & $\begin{array}{l}0.078 * * * \\
(0.024)\end{array}$ \\
\hline $\begin{array}{l}\text { Deviation between } \mathrm{j} \text { and } \\
\mathrm{i} \text { invest }\end{array}$ & & & & & $\begin{array}{l}0.094 * * * \\
(0.006)\end{array}$ & \\
\hline $\begin{array}{l}\text { Received reward points } \\
\text { lagged } \\
\text { Loss (lagged) }\end{array}$ & & $\begin{array}{l}0.137 * * * \\
(0.019) \\
0.314 * *\end{array}$ & $\begin{array}{l}0.137 * * * \\
(0.019) \\
0.314 * *\end{array}$ & $\begin{array}{l}0.012 * * * \\
(0.002) \\
0.027 * *\end{array}$ & $\begin{array}{l}0.092 * * * \\
(0.013) \\
0.332 * * *\end{array}$ & $\begin{array}{l}0.136 * * * \\
(0.016) \\
0.262 * * *\end{array}$ \\
\hline Period & $\begin{array}{l}-0.014 * * * \\
(0.003)\end{array}$ & $\begin{array}{l}(0.150) \\
-0.016^{* * *} \\
(0.003)\end{array}$ & $\begin{array}{l}(0.150) \\
-0.016^{* * *} \\
(0.003)\end{array}$ & $\begin{array}{l}(0.013) \\
-0.001 * * * \\
(0.000)\end{array}$ & $\begin{array}{l}(0.119) \\
-0.001 \\
(0.001)\end{array}$ & $\begin{array}{l}(0.097) \\
-0.003 \\
(0.002)\end{array}$ \\
\hline First period & $\begin{array}{l}0.772 * * * \\
(0.160)\end{array}$ & $\begin{array}{l}0.628 * * * \\
(0.161)\end{array}$ & $\begin{array}{l}0.962 * * * \\
(0.227)\end{array}$ & $\begin{array}{l}0.086 * * * \\
(0.024)\end{array}$ & & $\begin{array}{l}-0.200 \\
(0.147)\end{array}$ \\
\hline Final period & $\begin{array}{l}0.129 \\
(0.152)\end{array}$ & $\begin{array}{l}0.003 \\
(0.147)\end{array}$ & $\begin{array}{l}0.701 * * * \\
(0.196)\end{array}$ & $\begin{array}{l}0.062 \\
(0.019)\end{array}$ & & $\begin{array}{l}0.076 \\
(0.114)\end{array}$ \\
\hline Risk aversion & & $\begin{array}{l}-1.285^{* * *} \\
(0.451)\end{array}$ & $\begin{array}{l}-1.256^{* * *} \\
(0.474)\end{array}$ & $\begin{array}{l}-0.111^{* *} \\
(0.044)\end{array}$ & $\begin{array}{l}-0.806^{* *} \\
(0.327)\end{array}$ & $\begin{array}{l}-1.219 * * * \\
(0.236)\end{array}$ \\
\hline $\begin{array}{l}\text { Demographics } \\
\text { Constant }\end{array}$ & $\begin{array}{l}\text { no } \\
-3.998 * * * \\
(1.103) \\
\end{array}$ & $\begin{array}{l}\text { no } \\
2.262 \\
(2.764) \\
\end{array}$ & $\begin{array}{l}\text { yes } \\
2.291 \\
(3.324) \\
\end{array}$ & & $\begin{array}{l}\text { yes } \\
3.672 \\
(2.652) \\
\end{array}$ & $\begin{array}{l}\text { yes } \\
6.135 * * * \\
(1.374) \\
\end{array}$ \\
\hline IMR & & & & & & $\begin{array}{l}1.899 * * * \\
(0.231)\end{array}$ \\
\hline $\begin{array}{l}\text { Observations } \\
\text { R2 }\end{array}$ & 2880 & 2808 & 2808 & & 2808 & $\begin{array}{l}1358 \\
0.52\end{array}$ \\
\hline $\begin{array}{l}\text { Log likelihood } \\
\text { Left censored obs. }\end{array}$ & $\begin{array}{r}-3473.3 \\
1485\end{array}$ & $\begin{array}{r}-3406.9 \\
1450\end{array}$ & $\begin{array}{c}-3306.2 \\
1450\end{array}$ & & -748.63 & \\
\hline
\end{tabular}

Notes: ${ }^{a}$ RE Tobit=Random Effect Tobit; ${ }^{b}$ RE GLS=Random Effects Generalized Least Squares; ${ }^{c}$ RE Probit=Random Effect Probit model;*** Significant at the 0.01 level; $* *$ at the 0.05 level; $*$ at the 0.1 level; Standard errors in parentheses. Final period is a dummy that takes the value 1 if period equals 40 and 0 otherwise. Risk aversion corresponds to the number of $\mathrm{A}$ lotteries chosen by the participant in the lottery game. Average invest on $x$ indicates the average of contribution of all group members except participant $\mathrm{j}$. Received reward indicates the number of points of reward received by the participant; Demographics includes dummy variables for gender and for master. "Abs. Neg dev. from average" indicates the absolute value of difference of investment in $\mathrm{x}$ between player $\mathrm{j}$ and average of others if deviation is negative and 0 otherwise. "Pos dev. from average" indicates the value of difference of investment in $\mathrm{x}$ between player $\mathrm{j}$ and average of others if deviation is positive and 0 otherwise.

Table 9 shows the results concerning the determinant of rewarding decisions. Most of independent variables in specifications presented in Table 9 are similar to those presented above. Interestingly we find that subjects reward in most of cases. However Table 9 also indicates that positive deviations from average are strongly rewarded while negative deviations incite participants to reduce reward. The positive and highly significant coefficient associated to the variable "Received points of reward in $\mathrm{t}-1$ " indicates that a non negligible part of rewarding decision can be explained by willingness to reciprocate previous received rewards, which also explains the large number of reward points assigned. 


\subsection{Consequences on Welfare of the introduction of Punishment and Reward Institutions}

In this section we investigate the social consequences of punishment and reward on welfare over time. Both direct and indirect effects of institutions are observed. Our findings are summarized in result 5 .

Result 5: Both punishment and rewards affect welfare positively by inciting the free riders' to increase their contributions, which in turn reduces the probability of a terrorist attack. However positive effects of punishments are counterbalanced by detrimental effects of sanctions imposed on both punishers and targets. In contrast, in the reward treatment, the positive incentive effect on welfare is reinforced by direct positive consequences of reward on payoffs.

Support for Result 5. Table 10 presents Random Effect probit models on the probability of a terrorist attack. It indicates that the probability of a terrorist attack is reduced with opportunity of rewarding or sanctioning the defectors. Column (2) of Table 10 reports the corresponding marginal effects of the random effect probit model presented in column (1). The marginal effect -0.092 for Reward shows that individuals who play under the reward treatment have a 9.2 percentage points lower probability of being hit by a terrorist attack than under the baseline treatment. Similarly, it amounts to 6.9 percentage points lower probability in the sanction treatment.

Table 11 shows how the reduction of probability of an attack translates into higher first stage payoffs in the sanction and reward treatment. The evidence of this positive effect is found by comparing first stage payoffs in the punishment and reward treatments (4103.70 and 4212.96, respectively) and payoff in the baseline (3989.16).

Figure 4: Average payoff gain of the first stage sanction/reward relative to the baseline treatment

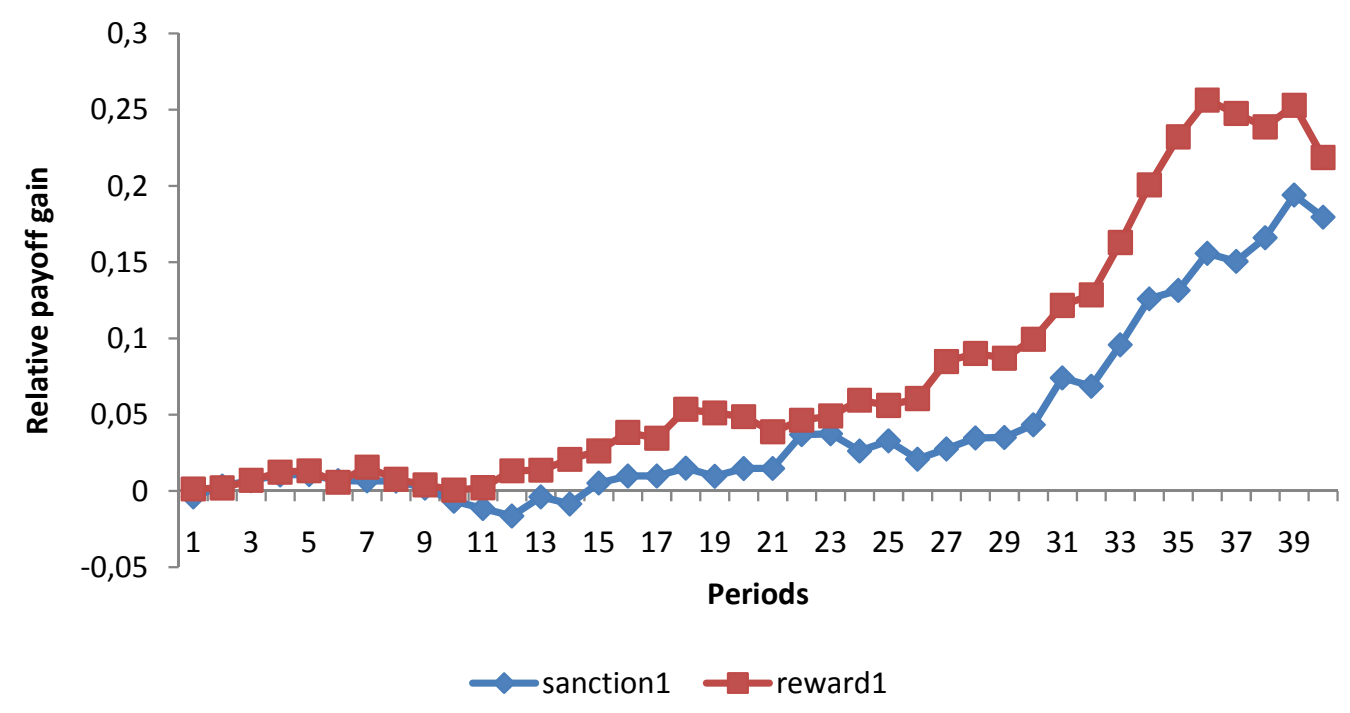




\section{Table10: Determinants of the occurrence of a terrorist attack}

\begin{tabular}{|c|c|c|}
\hline \multicolumn{3}{|c|}{ Dep. Var : probability of being hit } \\
\hline $\begin{array}{c}\text { Model : } \\
\text { Treatments }\end{array}$ & $\begin{array}{c}\text { RE Probit } \\
\text { All }\end{array}$ & dy/dx \\
\hline Reward & $\begin{array}{c}-0.242^{* * *} \\
(0.066)\end{array}$ & $\begin{array}{c}-0.092^{* * *} \\
(0.025)\end{array}$ \\
\hline Sanction & $\begin{array}{c}-1.831^{* * *} \\
(0.064)\end{array}$ & $\begin{array}{c}-0.069^{* * *} \\
(0.024)\end{array}$ \\
\hline Constant & $\begin{array}{c}4.762^{* * *} \\
(0.045)\end{array}$ & \\
\hline Observations & 3200 & \\
\hline Log likelihood & -2094.01 & \\
\hline
\end{tabular}

Table 11: Average Earnings in Each Treatment

\begin{tabular}{l|l|l|l|l|l}
\hline Treatment & \multicolumn{1}{|c|}{ Baseline } & \multicolumn{2}{c}{ Punishment } & \multicolumn{2}{c}{ Reward } \\
& Final profit & First stage profit. & Final profit & First stage profit. & Final profit \\
\hline & 3989.16 & 4103.70 & 3264.04 & 4212.96 & 8040.19 \\
\hline
\end{tabular}

Table 11 also shows that the positive effects of sanctions are counterbalanced by the existence of detrimental effects. Punishment induces a direct reduction of welfare by destroying resources of both the punisher and the target. The direct cost of punishment can be easily observed in Table 11 by comparing final and first-stage payoffs in the punishment treatment. The average cost of punishment amounts to 839.66 units. This result confirms the detrimental effect of punishment that has been observed in other studies (see notably Houser, Xiao, McCabe and Smith (2008)). In contrast, in the reward treatment, the positive incentive effect on welfare is increased by direct positive consequences of reward on payoffs.

Finally the global effects of punishment and reward are found in Table 11 by comparing final payoff in the punishment (reward) and baseline treatments. Average payoff in the punishment treatment (3264.04) is significantly lower than in the baseline treatment (3989.16), $(z=-2.875$, $\mathrm{p}<0.001)$. In contrast, Table 11 shows that final payoffs with reward (8040.19) are significantly larger than the average earnings in the baseline treatment $(\mathrm{z}=3.000 ; \mathrm{p}<0.001)$.

Figure 4 provides further information about the relative final payoff gain of the sanction treatment compared to the baseline. It shows the difference in the average group payoff between the punishment and the no-punishment condition and normalizes this difference by the average group payoff of the no punishment condition. This gives us the relative payoff gain of the punishment condition. Similar computations were realized for the reward treatment. Figure 4 shows that punishment treatment does not induce a relative gain before period 15 . We even observe a relative payoff loss between periods 10 and 15. This relative loss is less than 5 percent compared to the baseline. In contrast, in the final period the relative payoff gain is roughly 20 percent. Similarly, we find that reward treatment induce a relative gain compared to the baseline treatment. This gain amounts to about $25 \%$ in the final periods.

To sum while punishment succeeds in improving cooperation it fails (at least at short term) to increase welfare since detrimental effects induced by the implementation of punishment greatly exceed the positive effects on cooperation. 


\section{Conclusions}

This paper looks at how countries set collectively or privately their security policies against terrorism by using lab experiments. In this study we do not aim at replicating real-world terrorism activity per se. Instead we seek to test models of governments' offensive counterterrorism efforts. Precisely, we study to what extent international deterrence policy may suffer from the well known free riding problem. We also look at the effects of institutions that allow sanctioning and rewarding of other countries to facilitate coordination. In our game, a country could choose to invest in the international deterrence policy, invest instead its resources for its own national protection or choose to free ride by ignoring totally terrorism and invest on alternative projects.

We have three key findings. First, in absence of institutional incentives, most countries decide to invest in their own protection instead of contributing to the global counterterrorism policy. Our findings indicate that the decisions for those contributing to the collective security depend on their degree of risk aversion. In particular, more risk averse people invest more in international protection. Furthermore, consistent with the "probability neglect" theory, people contribute more for their protection after being hit in previous period.

Second, the introduction of institutions that allow sanctioning or rewarding of other group members improves significantly the contribution level to the collective security account. These results are consistent with previous results on VCM that showed that the introduction of rewarding and/or sanctioning mechanisms enhances significantly cooperation.

Third, while punishment improves cooperation it fails to improve welfare. The reason behind this result is that the detrimental effects of punishment generally offset the incentive effects induced by the sanctioning mechanism. In contrast, reward institution succeeds in improving welfare by inciting the free riders to contribute more to the global security policy, which in turn reduces expected loss from terrorism and by inducing a direct benefit to those who receive rewards. Our data also indicate that the positive effects of rewarding mechanisms on cooperation are even higher than those induced by punishment. This result is in sharp contrast with previous studies that found that punishment is more efficient than rewards to promote cooperation in VCM (Andreoni et al., 2003; Walker and Halloran, 2004; Sefton et al., 2007). These differences may be explained by some of our parameters of the experiment, in particular in the reward function. Our reward function may induce higher willingness to assign reward points in order to incite the other group members to reciprocate on these rewards, which is not necessarily the case in Sefton et al. (2007) and Walker and Halloran (2004). In Andreoni et al. (2003) this strategic motive to reward someone theoretically exists since the responder can at a cost of 1 cent, increase (decrease) the proposer's earning by 5 cents. However, unlike our experiment, in Andreoni et al.'s players are randomly rematched after each period, which prevents the use of reward points for strategic reasons.

The policy implications of our results are straightforward. Our paper stresses that, in absence of proactive policies that aim to sanction opportunistic decisions or reward cooperation, coordination in counterterrorism policies might be a difficult task. Our experiment replicates remarkably many predictions from previous theoretical study done by Sandler and Enders, (2004).

Many voices arise in the political era to defend the idea of a multilateral proactive response to terrorism. But the best type of response to have against terror is still open to debate. Our data provide support for enhancing coordination in counterterrorism through proactive policies, in particular those directed towards aiding poor and developing countries in exchange of a better cooperation against terror. One extension of this study would consist of implementing an experiment where the subjects could use a combination of both rewards and sanctions. 
Of course our results are not the final word on the matter. To keep the experimental model simple, we had to leave out many important features of terrorism concerns. Our research question looked at only two issues: the free riding problem in global counterterrorism policies and how reward and punishment institutions could overcome free riding. Nevertheless, there are many reasons to believe that coordination could still fail even after introducing economic incentives. Very much has to do with politics not economics, which by then, stand beyond the scope of this paper.

\section{References}

Abbink, K.; Irlenbusch, B. and Renner, E. (2000). "The Moonlighting Game: An Experimental Study on Reciprocity and Retribution", Journal of Economic Behavior and Organization, 2(42), pp. 265-77.

Anderson, C.M. and Putterman, L., (2006), "Do Non-Strategic Sanctions Obey the Law of Demand? The Demand for Punishment in the Voluntary Contribution Mechanism", Games and Economic Behavior, Vol. 54, No 1, pp. 1-24.

Andreoni J (1988) Why free ride? Strategies and learning in public goods experiments. J. Public Econ. 37:292-304.

Andreoni J. Harbaugh W. and Vesterlund L. (2003), "The Carrot or the Stick: Rewards, Punishments and Cooperation", American Economic Review, Vol. 93, No 3 pp. 893-902. Badey, T.J. (1998), "Defining International Terrorism: A Pragmatic Approach", Terrorism and Political Violence, 10 (1), pp. 90-107.

Berg J., Dickhaut J., and McCabe K. (1995), "Trust, Reciprocity and Social History", Games and Economic Behavior, Vol. 10, p. 122-142.

Bochet, O.; Page T. and Putterman, L., (2006). "Communication and Punishment in Voluntary Contribution Experiments." Journal of Economic Behavior and Organization. Vol. 60, pp. 1126

Bolton, G.E. and Zwick, R. (1995), “Anonymity versus Punishment in Ultimatum Bargaining”, Games and Economic Behavior, 10(1), pp. 95-121.

Bosman, R. and van Winden, F. (2005), "Global risk, investment, and emotions", working paper, University of Amsterdam.

Carpenter, J.P., (2007), "The demand for punishment", Journal of Economic Behavior \& Organization, Vol. 62, pp. 522-542.

Carpenter, J.P.; Matthews, P. and Ong'ong'a, O. (2004). "Why Punish? Social Reciprocity and the Enforcement of Pro-Social Norms", Journal of Evolutionnary Economics, Vol. 14.

Charness, G. (1996), “Attribution and Reciprocity in an Experimental Labor Market”, Mimeo, Universitat Pompeu Fabra.

Charness, G. and Haruvy, E. (2002), "Altruism, Equity, and Reciprocity in a Gift-Exchange Experiment: An Encompassing Approach", Games and Economic Behavior, 40(2), pp. 203-31. Charness, G.; Haruvy, E. and Sonsino, D. (2000), "Social Distance and Reciprocity: The Internet vs. the Laboratory." Mimeo, Technion.

Charness G. and Rabin M. (2002), "Understanding Social Preferences with Simple Tests", Quarterly Journal of Economics, 117(3), p. 817-869.

Clark, K. and Sefton, M. (2001). "The Sequential Prisoner's Dilemma: Evidence on Reciprocation", Economic Journal, Vol. 111(468), p. 51-68.

Croson, R.T.A. (2007), "Theories Of Commitment, Altruism And Reciprocity: Evidence From Linear Public Goods Games", Economic Inquiry, Vol. 45(2), p. 199-216.

Davis, D. and Holt, C. (1993), Experimental economics, Princeton University Press.

Desousa J., D. Mirza and T. Verdier (2009): "Terrorism and Trade: Does the Neighbour Hurt?", Paris School of Economics Working paper 
Dickinson, D.L. (2001), "The Carrot vs. the Stick in Work Team Motivation", Experimental Economics, Springer, Vol. 4(1), pp. 107-124, June.

Dickinson, D.L. (1998), "The voluntary contributions mechanism with uncertain group payoffs", Journal of Economic Behavior and Organization, 35, pp. 517-533.

John Duffy J. (2008) “Experimental Macroeconomics”, The New Palgrave Dictionary of Economics, Second Edition.

Dufwenberg, M. and Kirchsteiger, G. (2004), “A Theory of Sequential Reciprocity”, Games and Economic Behavior, Vol. 47, p. 268-98.

Egas, M., and Riedl, A., (2005). "The Economics of Altruistic Punishment and the Demise of Cooperation”, IZA Discussion Paper No.1646.

Enders, W., T.Sandler and J.Cauley (1990): "UN Conventions, Technology, and Retaliation in the Fight against Terrorism: An Econometric Evaluation", Terrorism and Political Violence, 2(1), p.83-105

Enders, W. and Sandler, T. (2006), "The Political Economy of Terrorism", Cambridge: Cambridge University Press.

Falk, A. and Fischbacher, U. (2006), "A Theory of Reciprocity", Games and Economic Behavior, Vol. 54 (2), p. 293-315.

Fehr, E. and Gächter, S. (2000), "Cooperation and Punishment in Public Goods Experiments", American Economic Review, Vol. 90, No 4, pp. 980-94.

Fehr, E. and Rockenbach, B. (2003), "Detrimental effects of sanctions on human altruism", Nature, 422(13), pp. 137-140.

Fischbacher, U. (2007), "z-Tree: Zurich Toolbox for Ready-made Economic Experiments", Experimental Economics, Vol. 10(2), p. 171-178.

Frey B.S. (2004), "Dealing with Terrorism - Stick or Carrot?”, Edward Elgar Publishing.

Frey, B.S. and Luechinger, S. (2004), "Decentralisation as a Disincentive to Terror", European Journal of Political Economy, Vol. 20(2), p: 509-515.

Gachter, S. and Falk, A. (2002), "Reputation and Reciprocity: Consequences for the Labour Relation ", Scandinavian Journal of Economics, Blackwell Publishing, vol. 104(1), p. 1-26.

Hamilton, L. C., and Hamilton, J. D. (1983), "Dynamics of terrorism", International Studies Quarterly, Vol. 27, p. 39-54.

Hess, R.O. Holt, C.A. and Smith A.M.(2007), "Coordination of strategic responses to security threats: Laboratory evidence”, Experimental Economics, Vol. 10, No 3, p. 235-250.

Hoffman, B. (1998), Inside Terrorism. New York: Columbia University Press.

Holt, C.A. and Laury, S.K. (2002), "Risk Aversion and Incentive Effects", American Economic Review, Vol. 92, No 5 pp. 1644-1655.

Houser, D.E.; Xioa, E.; McCabe, K. and Smith V. (2008), "When punishment fails: Research on sanctions, intentions and non-cooperation", Games and Economic Behavior, 62(2), pp.509532.

Isaac MR, Walker JM, Thomas SH (1984) Divergent evidence on free-riding: An experimental examination of possible explanations. Public Choice 43:113-149.

Isaac MR, Walker JM (1988) Communication and free riding behavior: The voluntary contributions mechanism. Econ. Inquiry 26(4):585-608.

Keser C., and Montmarquette C. (2008), "Voluntary contributions to reduce expected losses", Journal of Economic Behavior and Organisations, 66(2), pp. 477-491.

Keser, C. and van Winden, F. (2000), " Conditional Cooperation and Voluntary Contributions to Public Goods", Scandinavian Journal of Economics, Vol. 102(1), p. 23-39.

Kruger, A.B. and Maleckovia, J. (2003), "Education, Poverty and Terrorism: Is there a Causal Connection", Journal of Economic Perspectives, pp.119-144.

Lapan, H.E. and Sandler. T. (1988), “ To Bargain or Not To Bargain?: That Is the Question”, American Economic Association Paper and Proceedings, 78, p.16-20. 
Lichbach, M.I. (1987), “ Deterrence or escalation?: the puzzle of aggregate studies of repression and dissent", Journal of Conflict Resolution, Vol. 31, p. 266-297.

Masclet, D.; Noussair, C.; Tucker, S. and Villeval, M.C., (2003), "Monetary and NonMonetary Punishment in the Voluntary Contributions Mechanism", American Economic Review, Vol. 93, No 1, pp. 366-80.

Midlarsky, M.I.; Crenshaw, M. and Yoshida, F. (1980), "Why Violence Spreads: The Contagion of International Terrorism", International Studies Quarterly, Vol. 24, No. 2, pp. 262.298.

Nikoforakis, N. and Normann, H.-T. (2008), “A Comparative Statics Analysis of Punishment in Public Goods

Experiments", Experimental Economics, Vol. 11, pp 358-369.

Nikoforakis, N., Normann, H.-T., Wallace, B. (2008). "Asymmetric Punishments in PublicGood Experiments", Royal Holloway, University of London, mimeo.

Offerman, T. (2002), "Hurting Hurts More Than Helping Helps", European Economic Review, 46(8), pp. 1423-37.

Plott, C.R., 1991: "Will Economics Become an Experimental Science?" Southern Economic Journal 57 (April 1991):901-919. Reprinted in Experiments in Environmental Economics, Volumes I and II, edited by Jason F. Shogren (2006).

Rabin, M. (1993), "Incorporating Fairness into Game Theory and Economics", American Economic Review, Vol. 83, p. 1281-1302.

Rosendorff and Sandler, 2005

Sandler, T. Controlling Transnational Terrorism: Cooperation Dilemma, School of

International Relations, University of Southern California, Dec 2003.

Sandler T. and and Enders W. (2004), "An Economic Perspective on Transnational Terrorism", European Journal of Political Economy, Vol. 20, pp. 301 - 316

Sandler, T.; Tschirhart, T. and Cauley, J. (1983), "A Theoretical Analysis of Transnational Terrorism” American Political Science Review, Vol. 77, p. 36-54.

Schelling, T.C. (1993), “What Purposes Can 'International Terrorism' Serve?”, in R.G. Frey and Christopher W. Morris, eds., Violence, Terrorism, and Justice (New York: Cambridge University Press, 1991), p.18-32.

Schmid, A. and Jongman, A (1988), "Political Terrorism : A New Guide to Actors, Authors, Concepts, Data Bases, Theories and Literature”, New York, Transaction, « Theories », pp. 61135.

Scott, J.L., (1991), "Reputation building in hostage incidents", Defense Economics, Vol. 2 (3), p. 209-218.

Sefton, M., Shupp, R. and Walker, J. (2007), "The Effect of Rewards and Sanctions in Provision of Public Goods", Economic Inquiry, Vol. 45, pp. 671-690.

Selten, R. and Stoecker, R. (1986), "End behavior in sequences of finite Prisoner's Dilemma supergames A learning theory approach", Journal of Economic Behavior and Organization, Elsevier, vol. 7(1), p. 47-70.

Selten, R. (1978), “The Chain Store Paradox”, Theory and Decision,,Vol. 9, p.127 Slovic, P. (2000), "The Perception of Risk", London: Earthscan Publications.

Steinberg, Guido (2008), 'The Islamic jihad union', SWP Comments paper series .

Steinberg, Guido \& I. Werenfels (2007), 'Al-qaida in the maghreb: Just a new name or indeed a new threat?', SWP Comments paper series

Sunstein, C. (2002), "Probability Neglect: Emotions, Worst Cases, and Law?", Yale Law Journal, Vol. 112, p. 61-107.

Tversky, A. and Kahneman, D. (1974). "Judgment under uncertainty: Heuristics and biases", Science 185: pp.1124-1131. 
Tversky, A and Kahneman, D. (1971), "Belief in the law of small numbers", Psychological Bulletin 76 (2): 105-110.

Walker, J.M and Halloran, M. (2004), "Rewards and Sanctions and the Provision of Public Goods in One Shot Settings", Experimental Economics, Vol. 7, pp. 235-247.

Zizzo, D.J. (2003), "Money burning and rank egalitarianism with random dictators", Economics Letters, Vol. 81(2), p. 263-266.

\section{Appendix}

\section{Appendix Theoretical model}

Let's consider $\mathrm{n}$ participants endowed each with an initial wealth $\mathrm{W}$. At each period, the participants receive an endowment $d$ to allocate between three alternatives: international security policy, national security and an alternative project.

Let $X(X=0,1, \ldots, d), Y(Y=0,1, \ldots, d)$ and $Z(Z=0,1, \ldots, d)$, the amounts invested by a participant in the collective security policy $\mathrm{X}$, national protection $\mathrm{Y}$ and in the other alternative policy $\mathrm{Z}$, respectively. At each period, each participant has to allocate her endowment $d$ between $X, Y$, and $Z$. An international attack can occur with a probability $\mathrm{P}(\mathrm{A}=1)$. In case of occurrence of an attack, the conditional probability of being hit is given by $\mathrm{P}(\mathrm{H}=1)$. If hit, a participant incurs a loss $\mathrm{c}$.

Assuming risk neutrality, the expected individual payoff of this game is :

$$
\begin{aligned}
& \mathrm{E}=\mathrm{P}(\mathrm{A}=0) *(\mathrm{~d}-\mathrm{X}-\mathrm{Y})+\mathrm{P}(\mathrm{A}=1) * \mathrm{P}(\mathrm{H}=0) *(\mathrm{~d}-\mathrm{X}-\mathrm{Y})+\mathrm{P}(\mathrm{A}=1) \\
& \mathrm{P}(\mathrm{H}=1) *(\mathrm{~d}-\mathrm{X}-\mathrm{Y}-\mathrm{c}) \\
= & (\mathrm{d}-\mathrm{X}-\mathrm{Y})-\mathrm{P}(\mathrm{A}=1) * \mathrm{P}(\mathrm{H}=1) * \mathrm{c}
\end{aligned}
$$

Each token invested in $X$ reduces the probability of an international attack. The following equation defines the probability $\mathrm{P}(\mathrm{A}=1)$ of the occurrence of a terrorist attack:

$\mathrm{P}(\mathrm{A}=1)=\mathrm{p}^{*}-\left(\mathrm{X}_{\mathrm{i}}+\sum_{\mathrm{i} \neq \mathrm{j}} \mathrm{X}_{\mathrm{j}}\right) \frac{\mathrm{a}}{\mathrm{nd}}$

Where $\mathrm{p}^{*}$ is the probability of an international attack if no one invests in international protection. The second term of equation (2) shows how the probability of an international attack declines with the group's contribution to the collective security policy X. If all participants invest all their tokens $\mathrm{d}$ in X, this probability is reduced by a.

If a terrorist attack occurs it is assumed that one player among the $\mathrm{n}$ participants will incur a loss $\mathrm{c}$. For each participant $i$, the conditional probability of being hit $\mathrm{P}(\mathrm{H}=1)$ depends on the amount $\mathrm{Yi}$ she invested in the national protection relatively to the amount invested by the others. The following equation defines this conditional probability for participant $\mathrm{i}$ :

$\mathrm{P}(\mathrm{H}=1)=\frac{1}{\mathrm{n}}-\frac{1}{\mathrm{nd}}\left(\mathrm{Y}_{\mathrm{i}}-\frac{\sum \mathrm{Y}}{\mathrm{n}}\right)$

If all participants invest nothing in $\mathrm{Y}$ or exactly the same amount, the conditional probability of being hit is $1 / \mathrm{n}$ for all. This conditional probability is reduced (increased) by a given factor for the participant investing more (less) than the mean investment in Y. Y corresponds to a private good in terms of a private insurance. $\mathrm{c}$ is the cost of being hit. The expected payoff for the player $\mathrm{i}$ can be rewritten:

$E_{i}=(d-X-Y)-\left[p^{*}-\left(X_{i}+\sum_{i \neq j} X_{j}\right) \frac{a}{n d}\right] \cdot\left[\frac{1}{n}-\frac{1}{n d}\left(Y_{i}-\frac{\sum Y}{n}\right)\right] \cdot c$

It can be easily shown from equation (4) that the optimal strategy for each player $i$ is to invest all her endowment into $\mathrm{Y}$ since the return to a token allocated to the national protection $\mathrm{Y}$ exceeds the expected reduction of the probability of an international attack associated with placing the same token in the international counterterrorism action X.

Let's consider first whether it is optimal for player i to deviate from the equilibrium situation where all players invest all their endowment into $Y$ by investing an amount into $X$. Player i's expected payoff if all players including herself invest all their endowment into $Y\left(X_{i}=X_{-i}=0, Y_{i}=Y_{-i}=d, Z_{i}=Z_{-i}=\right.$ 0 , ) is given by :

$E\left(X_{i}, X_{-i}\right):\left[p^{*}-0 \frac{a}{n d}\right] \cdot\left[\frac{1}{n}-\frac{1}{n d}\left(d-\frac{n d}{n}\right)\right] \cdot c=-p^{*} \frac{c}{n}$ 
Suppose now that there is at least one player $\mathrm{i}$ who chooses $\mathrm{Xi}>0$. If player i chooses $\mathrm{Xi}>0$, then player i's expected payoff by investing a positive amount $\varepsilon$ into $\mathrm{Y}$ is given by :

$$
\begin{gathered}
E_{i}=-p^{*} \frac{c}{n}-\left[\frac{1}{n} p^{*} c \frac{\varepsilon(n-1)}{n d}-\frac{a \varepsilon}{n^{2} d} c-\frac{1}{n} \frac{a \varepsilon^{2}(n-1)}{n^{2} d^{2}} c\right] \\
=(v)-\left[\frac{1}{n} p^{*} c \frac{\varepsilon(n-1)}{n d}-\frac{a \varepsilon}{n^{2} d} c-\frac{1}{n} \frac{a \varepsilon^{2}(n-1)}{n^{2} d^{2}} c\right]=(v)-\Phi
\end{gathered}
$$

Where $\Phi=\left[\frac{1}{n} p^{*} c \frac{\varepsilon(n-1)}{n d}-\frac{a \varepsilon}{n^{2} d} c-\frac{1}{n} \frac{a \varepsilon^{2}(n-1)}{n^{2} d^{2}} c\right]$ and (v) is the expected payoff for the player $i$ when all participants invest all their tokens in the private insurance good $\mathrm{Y}$.

$\mathrm{Yi}$ is a dominant strategy for player i if $\Phi>0$.

$$
\begin{gathered}
\Phi=\left[\frac{1}{\mathrm{n}} \mathrm{p}^{*} \mathrm{c} \frac{\varepsilon(\mathrm{n}-1)}{\mathrm{nd}}-\frac{\mathrm{a} \varepsilon}{\mathrm{n}^{2} \mathrm{~d}} \mathrm{c}-\frac{1}{\mathrm{n}} \frac{\mathrm{a} \varepsilon^{2}(\mathrm{n}-1)}{\mathrm{n}^{2} \mathrm{~d}^{2}} \mathrm{c}\right]>0 \Leftrightarrow \mathrm{p}^{*} \varepsilon(\mathrm{n}-1)-\mathrm{a} \varepsilon-\frac{\mathrm{a} \varepsilon^{2}(\mathrm{n}-1)}{\mathrm{nd}}>0 \\
\Leftrightarrow \varepsilon<\frac{\mathrm{nd}\left[\mathrm{p}^{*}(\mathrm{n}-1)-\mathrm{a}\right]}{\mathrm{a}(\mathrm{n}-1)}
\end{gathered}
$$

This condition is always verified with our parameters for all $\varepsilon \in[0, \mathrm{~d}]$.

Suppose now that player i chooses $Y_{i}=d-\varepsilon$ andZ $Z_{i}=\varepsilon$, then his payoff is given by:

$\mathrm{E}_{\mathrm{i}}=\varepsilon-\mathrm{p}^{*}\left[\frac{\varepsilon}{\mathrm{nd}}+\frac{\mathrm{nd}-\varepsilon}{\mathrm{n}^{2} \mathrm{~d}}\right] \mathrm{c}$

Yi is a dominant strategy for player $i$ if:

$\varepsilon-\mathrm{p}^{*}\left[\frac{\varepsilon}{\mathrm{nd}}+\frac{\mathrm{nd}-\varepsilon}{\mathrm{n}^{2} \mathrm{~d}}\right] \mathrm{c}<-\frac{\mathrm{p}^{*} \mathrm{c}}{\mathrm{n}} \quad \Leftrightarrow \varepsilon\left[1-\frac{\mathrm{p}^{*}}{\mathrm{nd}} \mathrm{c}+\frac{\mathrm{p}^{*}}{\mathrm{n}^{2} \mathrm{~d}} \mathrm{c}\right]<0$

This condition is always verified with our parameters for all $\varepsilon \in[0, d]$.

\section{Appendix. Instruction (translated from french)}

You are now taking part in an economic experiment of decision making. The instructions are simple. If you read the following instructions carefully, you can, depending on your decisions and the decisions of others, earn money. It is therefore very important that you read these instructions with care. The instructions we have distributed to you are solely for your private information. It is prohibited to communicate with the other participants during the experiment.

At the end of the experiment your entire earnings from the experiment will be immediately paid to you in cash. During the experiment your entire earnings will be calculated in points. At the end of the experiment the total amount of points you have earned will be converted to euro at the following rate: $230 \mathrm{UME}=1 €$.

At the beginning of the experiment, you will be assigned to a group of 4 . The experiment is divided into 40 periods. The composition of the groups remains unchanged during the experience.

In this experiment, you will be front of events which could generate losses. You will have opportunity to reduce the probability of events occurring by investment in different projects. Every period is independent. Each period consists of two stages. At the beginning of first stage of each period, you will get an endowment of 20UME you will have to allocate between three projects: X, Y and Z. You can invest all or a part of your endowment in $\mathrm{X}$. The return on your investment in $\mathrm{X}$ is public. Each UME invests in $X$ reduces the probability of events which can generate or not a loss 600UME for one member of the group. You can also invest all or a part of your endowment in Y. The return on your investment in $\mathrm{Y}$ is private. Each UME invested in $\mathrm{Y}$ reduces your probability of being hit conditional to the fact that the event occurs. Finally, you can invest all or a part of your endowment in Z. For each UME invested in Z, you earn 1 UME. At the end of this stage, your earning depends on your investments, the investments of the other members of your group and the occurring of the event. In the 
second stage, you will be informed about each other group member's investment. You can affect their earnings by assigning costly punishment points.

The instructions for each period are given in the detailed instructions.

\section{Detailed instructions}

At the beginning of the experiment you'll get 6000UME. Each period consists of two stages.

\section{First stage}

At the beginning of first stage of each period, you will get an endowment of 20UME you will have to allocate between three projects: $\mathrm{X}, \mathrm{Y}$ and $\mathrm{Z}$. Each of the four subjects simultaneously decides how much of his or her endowment he/she will contribute to $\mathrm{X}, \mathrm{Y}$ or $\mathrm{Z}$.

You can invest all or a part of your endowment in $\mathrm{X}$. The return on your investment on $\mathrm{X}$ is public. The total amount of UME contributed to $\mathrm{X}$ by the four group members (including your own contribution) reduces the probability of events which can generate or not a loss 600UME for one member of the group. If nobody invests in $\mathrm{X}$ then the probability of events is about $70 \%$. If all the four group members (including you) invest all their UME in X, then the probability is reduced by 16 points of $\%$ and is about $54 \%$. A first table (see Table 1a) gives the probability of events following the total UME invested in $\mathrm{X}$ by all the group members.

\section{[Table 1a]}

You can also invest all or a part of your endowment in $\mathrm{Y}$. The return on your investment on $\mathrm{X}$ is private. Each UME invested in Y reduces the probability that you will be hit conditionally to the fact that the event occurs. Indeed, the probability of being hit conditional to the fact that the event occurs is initially the same for each group members: $25 \%$ (1/4). Only one of the group members will be hit in case of events occurring. However, this probability of being hit could be modified according to your investment in $\mathrm{Y}$ and the one of the three other group members.

We can distinguish three cases:

-If your investment in $\mathrm{Y}$ is equal to the average investment of your group, then your probability of being hit remains unchanged and is equal to $25 \%$.

-If you invest more in $\mathrm{Y}$ than the average investment of your group, then your probability of being hit is decreased by 1.25 points of $\%$ for each UME invested above the average investment of the group.

-If you invest less in $Y$ than the average investment of your group, then your probability of being hit is increased by 1.25 points of $\%$ for each UME invested below than the average investment of the group.

If you don't invest any UME in Y whereas the three other group members invest all their endowment in $\mathrm{Y}$, then in case of events occurring, your probability of being hit is equal to $43.75 \%$. If you invest all your endowment in Y whereas the three other group members don't invest any UME in Y, then in case of events occurring, your probability of being hit is equal to $6.25 \%$. If all group members (including yourself) invest exactly the same amount in $\mathrm{Y}$, then in case of events occurring, your probability of being hit remains equal to $25 \%$. A second table (see Table $1 \mathrm{~b}$ ) gives the probability of being hit conditional on events occurring according to the investment in $\mathrm{Y}$.

[Table 1b]

Finally, every UME that you invest neither in X nor in $\mathrm{Y}$ is automatically invested on $\mathrm{Z}$. For each UME invested in $Z$, you earn 1 UME.

After having decided how much of the $20 \mathrm{UME}$ you want to invest to $\mathrm{X}, \mathrm{Y}$ or $\mathrm{Z}$, by choosing a number between 0 and 20 for each project, you must press the OK button. Once you have done this, you can no longer change your decision for the current period. At the end of the first stage, the realisation or not of a loss $600 \mathrm{UME}$ is drawn at random following the number of UME invested in X by the group (Table 1a). If an event occurs, the probability that a specific individual being hit is drawn at random following the number of UME invested in Y (Table 1b). The gain for each participant at the end of the first stage is determined by his initial endowment of $6000 \mathrm{UME}$ at the beginning of the game adjusted at each 
period by an amount of $20 \mathrm{UME}$ minus the amounts invested on $\mathrm{X}$ and $\mathrm{Y}$ and minus the loss of 600 $\mathrm{UME}$ if the unfavourable event touches the individual.

\section{Second stage}

At the beginning of the second stage, your screen shows you how much each of your group members contributed to X. You have now the possibility to reduce or leave unchanged the income of each group member by distributing points. You can distribute points (between 0 and 10) to any member of your group. Each point you distribute to a particular player lowers his or her first stage earnings. Similarly, your income can be modified if the other group members wish to do so.

You are first informed about how much each group member contributed to the project $\mathrm{X}$ in the first stage. Please note that the order in which the contribution decisions of the three other subjects appear on your screen changes randomly each period (i.e. the first number which appears on your screen does not always correspond to the same subject).

You must decide how many points to give to each of the other three group members to reduce their income or leave it unchanged. You must enter a value for each subject, between 0 and 10 points. If you do not wish to change the income of a specific subject, then you must enter 0 .

If you distribute points, you bear a cost in UME which reduces your first stage earnings. This cost depends on the number of points you distribute to each subject. The more points you give to any subject, the higher your costs. Your total costs are equal to the sum of the costs of distributing points to each of the other three group members. The first line of table 2a illustrates the relation between points distributed to a subject and the cost of doing so in UME.

[Table 2a]

Suppose for example that you give 2 points to one subject. This costs you 10 UME. If you give 9 points to another subject, this costs you an additional $125 \mathrm{UME}$; if you give the last subject no point, this has no cost for you. In this example, your total costs of distributing points would be 135 UME $(10+125+$ 0 ). These costs will be displayed on your screen. As long as you have not pressed the OK button you can alter your decisions.

If you give no points to one subject, you don't affect his or her first stage earnings. On the each point you distribute to a particular player lowers his or her first stage earnings. Similarly, your income can be modified if the other group members wish to do so. The second line of table 2a illustrates the relation between points received and the cost in UME.

Note that in the calculation of the earnings, a maximum of 10 points is taken into account. Suppose for example that you received 3 points this lowers your first stage earnings about 60 UME. If you received 4 points this lowers your first stage earnings about 120 UME. If you received 10 points or more, then you lose 600 UME.

Your final income in ECU in each period for the two stages is therefore calculated as follows:

$=$ (income from the 1st stage) - cost of the points you have received - cost to you of points you distribute

The gain for each participant at the end of the experience is determined by his initial endowment of $6000 \mathrm{UME}$ at the beginning of the game adjusted at each period by the income from the first stage minus the cost of received points minus the cost of distributed points. 